\title{
Compulsory School-Based Enterprise Education as a Gateway to an Entrepreneurial Career
}

\author{
Piers Thompson \\ Economics Division, Nottingham Business School, $8^{\text {th }}$ Floor Newton Building, Nottingham \\ Trent University, Burton Street, Nottingham, NG1 4BU. UK \\ Email: piers.thompson@ntu.ac.uk
}

\author{
Caleb Kwong \\ Essex Business School, University of Essex, Southend-on-Sea, SS1 1LW, UK. \\ email: ckwong@essex.ac.uk
}

\section{Abstract}

This article explores the direct influence of school-based enterprise education on career choices and particularly, how this might be limited as entrepreneurial intentions dissipate over time. We propose that it is the indirect influence of schoolbased enterprise education, through encouraging voluntary engagement with other forms of enterprise education, which is important. Drawing upon data from the United Kingdom (UK) Global Entrepreneurship Monitor (GEM) study this paper utilises a binary logistic regression approach and finds evidence to support the proposed indirect role. This shows the importance of collaboration between those delivering and designing enterprise education at all stages to ensure that young people are prepared correctly to move seamlessly between such stages.

This is a post-print version of an article published in the International Small Business Journal:

Thompson, P. and Kwong, C. (2016) 'Compulsory School-Based Enterprise Education as a Gateway to an Entrepreneurial Career', International Small Business Journal, 34 (6), 838869. doi: $10.1177 / 0266242615592186$

which can be found in its final form at: 


\section{Compulsory School-Based Enterprise Education as a Gateway to an Entrepreneurial Career}

\section{Abstract}

This article explores the direct influence of school-based enterprise education on career choices and particularly, how this might be limited as entrepreneurial intentions dissipate over time. We propose that it is the indirect influence of school-based enterprise education, through encouraging voluntary engagement with other forms of enterprise education, which is important. Drawing upon data from the United Kingdom (UK) Global Entrepreneurship Monitor (GEM) study this paper utilises a binary logistic regression approach and finds evidence to support the proposed indirect role. This shows the importance of collaboration between those delivering and designing enterprise education at all stages to ensure that young people are prepared correctly to move seamlessly between such stages.

\section{Key Words}

Entrepreneurship Education; Business Starts; Entrepreneurial Intentions 


\section{Introduction}

In the UK, successive governments since the 1980s have attempted to transform the country into one of the world's most enterprising economies. This is to be achieved not only by generating an enabling enterprising context, but also by embedding an entrepreneurial mind-set (BIS, 2010; BERR, 2008). There has also been recognition that the development of an enterprise culture is a long term process, and exposure to entrepreneurship at a young age is crucial to develop entrepreneurial awareness and reduce fear of failure (BIS, 2010).

Consequently, considerable attention has been afforded to the role of enterprise education. The BIS (2010) report advocates that enterprise education be implemented at all levels from primary school to existing businesses; thus, the UK government provided $£ 360$ million between 2005 and 2008 to fund enterprise education in schools (Ofsted, 2011). A compulsory five days of entrepreneurship education has subsequently been introduced as part of the work-related learning curriculum (Gillie, 2012). Interventions involving compulsory participation have the advantage of potentially reaching a majority of the future workforce. Despite increased interest, school-based enterprise education remains a relatively less explored topic when compared to equivalent courses in universities (Peterman and Kennedy, 2003). There is little consensus regarding the immediate objectives of intervention at this level, with insufficient evidence to link it with business start-up (Carsrud and Brannback, 2011).

However, if the main objective of enterprise education is to develop an enterprising culture, as the UK government has stipulated, then our measures of effectiveness have to move beyond business start-up activity as the 'be-all and end-all'. A better understanding of the ways in which school-based enterprise education can support the development of enterprising individuals is crucial. The concept of an enterprising culture has long been criticised for its intangible qualities, which prohibit the development of precise measures of effectiveness (Jack and Anderson, 2002). This means there is a need to dissect the concept into more tangible and measurable objectives. Our study proposes measurements that would capture a crucial antecedent of enterprise culture, based on voluntary participation in enterprise education beyond school. Drawing on the theories of interest development from educational science (Hidi and Renninger, 2006), we argue that school-based enterprise education serves an important indirect role in sustaining entrepreneurial interest, until the realisation of these aspirations becomes feasible. Sustained interest is the first step towards the development of a lifelong passion for entrepreneurship; we argue that only where this is persistent and withstands the test of time can a true enterprise culture take root.

The critical focus of this article is to examine whether compulsory school-based enterprise education increases the probability that participants will subsequently participate voluntarily in further enterprise education and training. The secondary objective being to evaluate the possible impact that such sustained participation may have in changing the entrepreneurial intentions and behaviours of participants.

Our article provides evidence that compulsory enterprise education at school level does play a role in sustaining participant engagement. This development of sustained interest provides grounds for a holistic, centrally coordinated approach to enterprise education. Knowledge of this role allows policy makers to plan the provision of enterprise education over a longer period than previously considered, which may improve effectiveness. Regarding our second research objective, we present evidence that compulsory enterprise education at school level has little direct effect on 
entrepreneurial intentions and behaviours, but rather, further voluntary participation in university and government training schemes acts in a mediating fashion to provide an indirect link.

The article is organised as follows: Sections two and three review the existing enterprise education paradigms before introducing the theoretical concept of sustained interest. The GEM data and approaches utilised are outlined in Section four with results presented and discussed in Section five Section six concludes with theoretical and policy implications and limitations.

\section{Reviewing existing enterprise objective paradigms}

Although enterprising individuals have been seen as at the heart of an enterprise culture, there is little consensus as to what makes an individual enterprising. The traditional view focuses on those who are starting and developing a small business (Kourilsky, 1995), but others such as Keat (1991) note that small business owners are not particularly enterprising. Gibb (1987) suggests that the enterprising individual is a multifaceted construct encompassing both entrepreneurial and intrapreneurial behaviours. In the remainder of the section, we review three existing measures of enterprise intervention effectiveness. We argue that, whilst each is helpful in itself, they only measure the attributes of an enterprising individual and capture what constitutes an enterprise culture to a limited extent.

Focusing first upon the business start-up rate, this is a reflection of how successfully an enterprise culture is disseminated amongst the population. Venture creation is a measureable construct, although many studies suffer from issues of self-selection and reverse causality (Rideout and Gray, 2013; Fayolle et al., 2006). Early enterprise education scholars, particularly those in North America, and policy makers tend to see it as the benchmark of success for enterprise interventions and policy implementation (Kourilsky, 1995). However, few empirical studies, in particular those focusing on the secondary school context, found the connection satisfactory (Jones-Evans et al., 2006). A major problem with the measure is that venture creation may not necessarily reflect the objectives of the interventions; most notably, new venture creation requires skills, competencies, networks and resources beyond what is provided in a school context (Mahlberg, 1996). Rushing school leavers into starting a business may result not only in aspiring entrepreneurs taking unnecessary risks, but also in the creation of ventures that are arguably less growth and innovation orientated (Kwong and Thompson, 2015). Those wishing to engage in venture creation may logically wait until the additional attributes not provided at school are acquired (Carsrud and Brannback, 2011).

Second, the attitudinal transformation paradigm recognises that engaging in an entrepreneurial event for most school leavers is impractical, this has led to calls for enterprise education at this level to be primarily about developing an interest and awareness (Draycott et al 2011; Kwong et al., 2012a). Those who develop a positive attitude towards entrepreneurship are believed to be more inclined to start a business and support others to do the same. Effectiveness assessments within this paradigm draw from shorter timeframes and lower order constructs such as those classified as 'reaction' and 'learning' by Kirkpatrick (1959). Many of these measures are identified within Shapero and Sokol's (1982) Entrepreneurial Event (EE) and Ajzen's (1991) Theory of Planned Behaviour (ToPB) models as antecedents to entrepreneurial events, including perceived desirability, attractiveness, feasibility, self-efficacy and locus of control. With regard to achievement of these measures, findings have generally been more positive (Peterman and Kennedy, 2003; Man and Yu, 2007). However, there has been concern over the durability of the so-called stream-booster intervention programmes 
that are prevalent at the school level, as they require only passive commitment that does not demand action on the part of the learners.

Third, enterprise education has long been associated with the development of a variety of skillsets that are crucial to the development of enterprising individuals (Martin et al., 2013; Volery et al., 2013). These include the technical and functional start-up skills required to develop business proposals, implement strategies, and generate finance and marketing plans (Freel, 1999). It is also linked to improved entrepreneurial skills such as opportunity recognition (Morris et al., 2013), as well as soft skills such as the ability to act independently, initiate actions, set goals and targets, and cope with uncertainties (Draycott et al., 2011). The latter skills in particular would not only facilitate business start-up activities but also cater for diverse career aspirations, and are consistent with the view of the European Commission (2006) that entrepreneurship is a basic skill alongside digital skills and literacy. The disadvantage of skill development as a measure, however, is its incomparability (Morris et al., 2013). Programmes that are developed within the definition of a basic skill tend to be non-specialised, whilst others often place venture creation as the ultimate objective (McLarty et al., 2010). Consequently, few empirical studies have been conducted on an aggregate level with most existing studies being qualitative in nature (Rasmussen et al., 2011), or focussing on a specific programme (Dickson et al., 2008).

Each of these measures of effectiveness have their own strengths and limitations, but what is lacking is a common measure that would: a) measure an action post-intervention even when immediate venture creation or other entrepreneurial activities may not be realistically feasible; and b) reflect an entrepreneurial objective that is equally applicable to different interventions. In the next section, we propose the 'sustained interest paradigm', based on voluntary participation in enterprise education programmes beyond secondary school.

\section{Sustained interest in the context of enterprise culture and the development of enterprising individuals}

Studies have suggested that interest directs energy towards positive engagement with learning (Dean and Jolly, 2012); educational science literature on the phases of interest development has made a crucial distinction between sustained interest and shorter term situational interest (Hidi and Renninger, 2006). Whilst the latter can be triggered through a singular objective, for instance, the desire to pass a course, the former is not bound by context, and involves voluntary and often excessive effort that is driven by personal curiosity (Renninger and Shumar, 2002). Whilst both forms of interest are facilitative to learning (Edelson and Joseph, 2004), only the former is associated with the deeper level of learning that improves future recollection and application in a different context (Renninger and Hidi, 2002). Sustained interest is also found to induce self-regulatory behaviours: in other words, to take initiative to accumulate knowledge regarding the particular subject, overcome frustration and challenges, and anticipate subsequent steps to sustain long term constructive and creative endeavours, often with seemingly minimal effort (Lipstein and Renninger, 2007).

In the context of entrepreneurship, sustained interest is particularly important. Entrepreneurial pursuits require individuals to not only identify opportunities, but also to exploit them (Shane and Venkataraman, 2000) This is often a lengthy process that requires persistence and perseverance, and when pursuit of an opportunity does not go according to plan, individuals will need to invest additional effort without considering it a burden (Kwong and Thompson, 2015). There is also a need to recognise one's own limitations and to acquire new skills and resources accordingly (Cheung, 
2014). This often involves time away from the pursuit (Kwong and Thompson, 2015), and therefore, maintaining interest plays a key role. Internalising entrepreneurship and making it part of a person's passions and interests is thus valuable in not only offsetting some of the pressures of the immediate, but also in encouraging acceptance of an entrepreneurial lifestyle where there is a proactive effort to discover what entrepreneurship has to offer. Whilst sustained interest is largely self-generated (Hidi and Renninger, 2006), it benefits from external support (Renninger, 2000). Compulsory enterprise education at school can often be seen as the initial line of intervention where students are first exposed to the notion of entrepreneurship. Nevertheless, to develop a sustained interest, educational science research suggests intensity, diversity and repetitiveness of engagement is crucial (Csikszentmihalyi et al., 1993). We describe each of the factors prior to exploring ways in which enterprise education can contribute to the development of sustained interest in entrepreneurship.

\section{Intensity of exposure}

It is generally believed that the more intensive an engagement, the more likely that an interest in a subject will be sustained (Hidi and Renninger, 2006). In the context of entrepreneurship, intensive enterprise training programmes such as those in away day or boot camp formats are found to be highly effective in developing entrepreneurial aspirations, which are sustained over the medium term (Kwong et al., 2012c). Sustaining heightened aspirations with a one-off intervention programme can still be challenging, and studies suggest that positive attitudes towards the exposure do not always result in entrepreneurial behaviours (Carsrud and Brannback, 2011). This is because pressure of the immediate, such as preparing for an exam or finding a job upon graduation, may distract participants from their entrepreneurial ambitions (Kwong et al., 2012c), and suggests that intensity on its own may not be adequate in the development of sustained interest.

\section{Repetitive and continuous engagement over time}

Leinhardt et al.'s (2002) thesis on the 'island of expertise' suggests that repetitive and continuous engagement is an important factor in generating sustained interest. For instance, although a child's interest in a particular area, such as trains, can be triggered initially by an independent event, say receiving a toy train set as a present, interest in the subject can only be sustained through continuous engagement, for example, with related books and museum visits. In doing so, a wealth of knowledge around the topic is acquired, which further reinforces the interest and generates an embedded identity that binds the person to the specific subject. Without repeated exposure, however, this interest may fade over time. Repeated learning also contributes to the development of specialised knowledge (Leinhardt et al., 2002). Specialisation requires repeated exposure to domain-specific declarative knowledge, repeated practice in interpreting new content, making inferences to connect new knowledge to existing knowledge, and repeated conversations with others who share the same interests. Studies on expertise development suggest that a learner would normally need to spend 10,000 hours or about 10 years of practice in a domain before becoming expert (Hayes, 1985). Acquiring substantive interest in and knowledge of entrepreneurship most likely requires more than a single exposure; without repeated exposure the aspirations generated may dissipate over time (Lourenço et al., 2012; Kwong and Thompson, 2015).

\section{Diversity of exposure}

The theory of fluency development suggests that looking both within and across settings is essential in understanding the development of interest and competence (Barron, 2006). Different forms of engagement are important in the development of a common identity across communities, giving learners a broader sense of belonging and exposing them to a much wider support group (Barron, 
2006). Diversity of exposure is important because technical competencies are best developed through exposure to the same subject within multiple settings and access to varied resources, as this allows greater generalisation. Successful generalisation in turn, enables learners to develop a feeling of competence, and increases confidence that the skills acquired are relevant to life and society at large (Ladson-Billings, 1995). Diversity of exposure is of particular relevance in the context of entrepreneurship given the multi-layered nature of the enterprise culture construct which means different activities may be needed to bring out the entrepreneurial self of individuals.

Most current enterprise programmes are short in duration and often connected to educational and governmental establishments with specific agendas. As such, few programmes on their own can deliver the repetitive and diverse exposures that are required for sustained interest to develop. Repeated engagement with other forms of enterprise education would enable heightened interest generated through school-based enterprise education to be nurtured and sustained over a prolonged period of time. This would, in turn, enable aspiring entrepreneurs to accumulate appropriate skills, networks, finance and experiences for entrepreneurial activities without losing the initial interest. Such sustained exposure, we argue, would provide a base of entrepreneurial mindsets and skills, which in turn facilitates entrepreneurial behaviours. We recognise voluntary future participation in enterprise programmes to be an important 'mid-way' behavioural measure to assess the effectiveness of school-based enterprise education. As far as we are aware, no study has specifically examined the relationship between school-based enterprise education and further engagement in other forms of enterprise education programmes in the UK, although research has examined the effect of enterprise education on future reengagement with academic subjects. 


\section{Data Collection}

In order to examine the relationship between compulsory school-based enterprise education and a range of later stage sources of enterprise education, a data source covering a range of respondents from across the population is required. This is to capture all potential later stage enterprise education sources available for individuals to use. Longitudinal data covering a particular schoolbased enterprise intervention are one option. However, the length of time between the intervention and all potential follow up sources of education may make this infeasible in practice due to cost and high respondent attrition rates. This makes a large scale cross sectional dataset the most appropriate method of analysing this relationship. The main data utilised in this study are drawn from the Adult Population Survey of the GEM study (Reynolds et al., 2005) - an international study of entrepreneurial behaviour and attitudes, from England and Wales, between 2006 and 2007. The data collection method consists of telephone interviews using a stratified random sample, ensuring a minimum of 2000 respondents from each of the Government Office Regions, (for an exhaustive description of the data collection procedure utilised in the UK, see Levie (2007)). The data utilised covers those aged between 18 and 45 years $(n=16,343)$ reflecting the relatively recent expansion of entrepreneurship and small business based courses (Vesper, 1988; Vesper and Gartner, 1997; Kuratko, 2005; Solomon, 2007; Hannon, 2007).

A key advantage of the GEM data is that items are included in the survey that relate to respondent participation in enterprise education. The GEM data collects information on enterprise education and training undertaken by respondents at four different points in their career: (1) at school, (2) as a formal work placement, (3) at college or university (henceforth university), and (4) as part of a government sponsored training scheme. ${ }^{1}$ Although continuing education and the introduction of placements into university courses mean that it is possible for respondents to undertake these forms of education in a variety of orders, for the majority, school precedes other forms of education and training and thus, allows us to establish causational linkage between school-based and other forms of enterprise education. Those engaging with enterprise education may be a self-selecting sample with a higher proportion of participants displaying a prior desire to start a business as well as possessing greater pre-existing abilities (Fayolle and Gailly, 2015; Rideout and Grey, 2013). This limits the potential to determine the true impact that enterprise education has upon attitudes towards and propensity to engage with entrepreneurial activities, such as new venture creation. In order to minimise this problem the GEM study asks those that have undertaken enterprise education at any of the four stages above whether this was voluntary or compulsory.

Data Analysis

The main emphasis of this article is to consider whether enterprise education at school leads to greater voluntary involvement in other forms of enterprise education - the expectation being that school-based enterprise education given its temporal displacement from major career choices would only have a limited effect on the work decisions of those exposed to it. However, by encouraging

\footnotetext{
${ }^{1}$ Respondents were asked: "Have you ever taken part in any of the following? (i) Business or enterprise training at school?; (ii) Business or enterprise training at college or university?; (iii) Work experience in a small or medium sized business whilst at school or college?; (iv) A Government or public sector training course in business or enterprise skills?"
} 
individuals to engage with later-stage enterprise education it may play an important role in generating sustained interest. This would suggest that any effect of school-based enterprise education on entrepreneurial activity is being mediated by later stage enterprise education. In order to investigate whether this is the case two main sets of relationships need to be investigated.

As the probability of engaging in entrepreneurial activities and the educational choices associated with this have previously been found to be influenced by a wide variety of personal and environmental factors it is important to utilise an analysis approach that controls for these other factors. To control for these other factors a multiple regression approach is adopted. This allows the analysis to take advantage of the large sample sizes available from the GEM data in order to isolate the influence of engagement in enterprise education at various stages of development and by type of engagement with the programmes (compulsory and voluntary). The large sample sizes of the GEM data can lead to relatively small effects being statistically significant. Although this means that all influences on decisions to voluntary engage with later stage enterprise education can be identified, it might be misleading in terms of the importance of these results. In order to account for this the odds-ratios relating to focal results are also reported in the text to indicate the magnitude of the effect on the probability of undertaking the activities of interest.

The first set of regressions will investigate to what extent compulsory enterprise education at school increases the probability of an individual engaging voluntarily with enterprise education at later stages of their education and training. As our focus is on examining the subsequent impact of schoolbased enterprise education, we have chosen those voluntarily undertaking university enterprise courses, formal work placements in SMEs, or government sponsored enterprise training as our dependent variables. Given the discrete nature of these variables, ordinary least squares regressions are inappropriate and instead binary logistic regressions are utilised.

As noted above, in addition to compulsory school-based enterprise education a variety of personal and environmental factors are likely to influence the probability that an individual engages with later stage enterprise education with an intention to improve their entrepreneurial skills or start a new business in the future. These can be grouped into personal characteristics (PersChar) and environmental factors (Envir) as outlined in equation (1) below. The personal characteristics included in the regressions are intended to control for: human capital; liquidity constraints; the extent an individual is embedded in their local community as reflected by their migration status; work status; and gender. The environmental factors that are likely to influence the perceived desirability and feasibility of new venture creation include: the strength of the local economy; the presence of congestion or agglomeration effects; and other unobserved regional influences. The rationale for including each of the personal and environmental characteristics along with the measures used to represent them are discussed below.

(1) EntreEd Volj,i $_{i}=\alpha_{1}+\beta_{1}$ PersChar $_{i}+\gamma_{1}$ Envir $_{i}+\varphi_{1, j}$ EntreEd $_{\text {COMPSCH,i }}+\varepsilon_{1, i}$

Studies suggest that entrepreneurship and careers in general, are a planned behaviour (van Gelderen et al., 2008; Jaidi et al., 2011; Kautonen et al., 2013). This would suggest that personal characteristics that increase the likelihood of voluntarily engaging with later stage entrepreneurship are likely to be those associated with greater engagement with entrepreneurship and entrepreneurial careers in general. Individuals will engage with this later stage enterprise education as an investment to prepare themselves for their desired careers (Bae et al., 2014). Relevant human capital can be both in terms of experience and formal training and qualifications (Shane, 2008). Age 
is expected to have an inverted U-shaped relationship with entrepreneurship (Kim, 2007). This is a balance of the need to gain experience (Baum and Silverman, 2004), offset against the time required to obtain a return on the time and effort put into starting a business (Lévesque and Minniti, 2006). Experience is therefore, represented by the age of the respondent centred around the average age, and the square of this. Centring the age variable makes the zero value more meaningful and reduces the collinearity between the two age terms (Cohen et al., 2003). Those with higher levels of formal education are found to display better opportunity recognition and broader networks, which may be converted into greater entrepreneurial engagement (Arenius and De Clercq, 2005; Levie and Autio, 2008; Pickernell et al., 2011; Block et al., 2011). Recognising this, a dummy is included to represent the possession of university undergraduate degree level qualifications or above.

The impact of work-status is complicated as those in employment are likely to possess ties to more valuable network partners (Arenius and De Clercq, 2005). However, those out of work have a lower opportunity cost of engaging in entrepreneurship (Fairlie, 2013; Beladi and Kar, 2014). Dummies are included to represent the following: full-time employment; part-time employment; students; out of work claiming benefits (unemployment); out of work not claiming benefits (economically inactive); and a final group including those classing themselves as disabled, homemakers, and the retired. Those entering a region from another UK region (in-migrants), or from another country (immigrants) may look at the resources available and spot opportunities that lifelong residents of a region miss (Kalantaridis and Bika, 2006; Levie, 2007).

As studies continue to find differences in the entrepreneurial propensities of women and men (Brush, 1992; Klapper and Parker, 2011) a dummy variable is included to capture this. A number of possible explanations have been suggested: greater risk aversion (Caliendo et al., 2009); different family and social roles (Mueller and Conway Dato-on, 2013); direct discrimination (Marlow and Patton, 2005; Gicheva and Link, 2013); and perceived financial constraints (Kwong et al., 2012a; Carter et al., 2015). As financial capital is likely to be important in overcoming liquidity constraints (Evans and Jovanovic, 1989; Fairlie and Krashinsky, 2012; Lofstrom et al., 2014), household income dummies place individuals into three categories: less than $£ 17,500$; $£ 17,500$ to $£ 49,999$; and $£ 50,000$ or more.

The environmental influences include economic conditions, which make entrepreneurship more profitable and encourage entrepreneurial behaviour (Fotopoulos, 2014). These are captured by the unemployment rate (claimant count) in the local authority, which has a negative environmental level effect rather than the positive individual level effect discussed above (Ritsilä and Tervo, 2002). The second influence on entrepreneurial activity from the local environment is captured by the rural or urban nature of the economy as determined by the Office for National Statistics (2004) categorisation of wards within England and Wales. The relationship is unclear as rural areas tend to have a greater tradition of small business ownership and employment (Brooksbank et al., 2008) and lower costs from factors such as congestion (Frenken and Boschma, 2007; Delfmann et al., 2014). However, they lack the benefits of agglomeration economies which can include: clusters of similar firms (Delgado et al., 2010); specialised labour (Baker et al., 2005); and better information flows (Bunten et al., 2014).

In order to determine the effectiveness of compulsory school-based enterprise education it is necessary to consider its indirect effect on entrepreneurial attitudes and activities. The first part of the analysis considers the link with later stage enterprise education. The second part then considers 
whether there is a positive relationship between voluntary engagement with later stage enterprise education and entrepreneurial activities. This completes the causal chain from compulsory enterprise education at school to enterprise activities and behaviour. As discussed in the preceding sections, the benefits of enterprise education are not presumed to be restricted to outcomes associated with new venture creation and business ownership. As such, it would be preferable to investigate the link between voluntary engagement with later stage enterprise education and a broader measure of entrepreneurship, which incorporates both business ownership and intrapreneurship. Unfortunately, the GEM survey conducted in 2006 and 2007 did not include such a measure. This means that although imperfect we consider the mediating effect of later stage enterprise education on the relationship between compulsory school-based enterprise education and entrepreneurial intentions and nascent entrepreneurship.

The first measure, entrepreneurial intentions, is defined as those who feel that they will be involved in starting a business that they will own or part own and manage in the next three years. This means that this measure requires no commitment towards an entrepreneurial career, and a large number of this group may never actually instigate their business ideas. The second measure, nascent entrepreneurship, includes those that have actively engaged in starting a business. They must have undertaken at least one activity associated with starting their business, but these businesses are at the earliest stage of development, and have not paid profits or wages for more than three months in total ${ }^{2}$.

Baron and Kenny (1986) suggest that a mediating relationship such as that described above can be examined by looking at three key relationships. First, they suggest that the independent variable should be significantly related to the dependent variable. In the example here compulsory schoolbased enterprise education should be significantly related to entrepreneurial intentions or nascent entrepreneurship (EntreAct) as outlined in equation (2) below. Second the independent variable should be significantly related to the intervening variable. This refers to our main relationship of interest discussed above (equation (1)), in other words, the role of compulsory enterprise education in encouraging further voluntary engagement with later stage enterprise education. Third, when the intervening variable is controlled, any relationship between the independent variable and dependent variable should become insignificant. Thus, if later stage enterprise education completely mediates the relationship between compulsory school-based enterprise education and entrepreneurial careers (as captured by entrepreneurial intentions and nascent entrepreneurship) its inclusion in the regression of entrepreneurial activity should result in a non-significant relationship between compulsory enterprise education and entrepreneurial activity. This is shown by equation (3) where the impact of enterprise education is captured by the variable EntreEd ${ }_{v o L j}$ where the subscript $j$ reflects the level, school $(S C H)$, university (UNI), work placement (WP) or government training scheme (GOV). A mediating relationship would result in $\varphi_{3}$ becoming insignificant and $\varphi_{4}$ being significant.

(2) EntreAct $_{i}=\alpha_{2}+\boldsymbol{\beta}_{2}$ PersChar $_{i}+\gamma_{2}$ Envir $_{i}+\varphi_{2}$ EntreEd $_{\text {COMPSCH,i }}+\varepsilon_{2, i}$

\footnotetext{
${ }^{2}$ To confirm that nascent entrepreneurs will be activity involved in the business follow up questions ask them to confirm that they will be owners or part owners of the resultant business, and that they will be actively involved in the management of the business. See Reynolds et al. (2005) for a detailed explanation of the questions used to define various stages of entrepreneurial engagement.
} 
(3) EntreAct $_{i}=\alpha_{3}+\beta_{3}$ PersChar $_{i}+\gamma_{3}$ Envir $_{i}+\varphi_{3}$ EntreEd $_{\text {COMPSCH,i }}+\varphi_{4, j}$ EntreEd $_{\text {Volj,i }}+\varepsilon_{3, i}$

Within the regressions we control for compulsory engagement with the relevant later stage enterprise education source in both equations (2) and (3), as their compulsory nature should mean that compulsory school-based enterprise education does not cause this engagement. Each of the later stage sources of enterprise education are examined in separate regressions as there is the danger of multicollinearity as those voluntarily engaging in later stage enterprise education could engage in more than one source.

It should be noted that given the nature of the activities being studied, models are better at estimating those factors associated with a greater probability of engagement rather than actually undertaking the activity. For example, Shapero and Sokol's (1982) model of the entrepreneurial event suggests that individual intentions are formed from the perceived desirability and feasibility of the activity, but for such intentions to become realised often requires a trigger event. These trigger events are often out of the control of the individual, such as the loss of full time employment for others and cannot be predicted by the model.

The mediating relationship proposed is depicted in Figure 1. Here compulsory school-based enterprise education may be found to have a positive relationship with entrepreneurial intentions or nascent entrepreneurship as captured by a significant coefficient $\varphi_{2}$ in equation 2 .

\section{PLEASE INSERT FIGURE 1 ABOUT HERE}

The links at the top of Figure 1 depict the mediation of this relationship through voluntary later stage enterprise education. Here compulsory school-based enterprise education leads to voluntary engagement with voluntary later stage enterprise education (equation 1 coefficient $\varphi_{1}$ ), which then leads to greater entrepreneurial intentions and nascent entrepreneurship (equation 3 coefficient $\varphi_{4}$ ). With complete mediation the direct link from compulsory school-based enterprise education to entrepreneurial intentions and nascent entrepreneurship should be no longer significant (coefficient $\varphi_{3}$ in equation 3). However, as a partial mediating relationship may be present, $\varphi_{3}$ need not become insignificant. This means the key results for mediation being present, are coefficients $\varphi_{1}$ and $\varphi_{4}$ being significant (Kenny et al., 1998). It is also possible that the indirect effect via the mediating variable $\left(\varphi_{1}\right.$ and $\left.\varphi_{4}\right)$ could have the opposite relationship to the direct effect $\left(\varphi_{3}\right)$. This means that coefficient $\varphi_{3}$ could remain significant, but also means coefficient $\varphi_{2}$ in equation 2 could be insignificant as the two effects cancel out (MacKinnon et al., 2000).

Alternative approaches to testing for mediating relationships include testing the differences in the relationship between the independent variable when the mediating variable is and is not included in regressions of the dependent variable. In this case it would mean considering if there is a significant difference in the coefficients $\varphi_{2}$ and $\varphi_{3}$. In other words the difference in the effect of compulsory school-based enterprise education on entrepreneurial intentions or nascent entrepreneurship when voluntary later stage enterprise education is, and is not accounted for; this allows for partial mediation and full mediation to be identified. Freedman and Schatzkin (1992) propose a t-test of the difference in $\varphi_{2}$ and $\varphi_{3}$ where the standard error of this is given by:

$\sigma_{\text {Freedman-Schatzkin }}=\sqrt{\sigma_{\varphi 2}^{2}+\sigma_{\varphi 3}^{2}-2 \sigma_{\varphi 2} \sigma_{\varphi 3} \sqrt{1-\rho_{X I}^{2}}}$

Where $\sigma_{\varphi 2}$ and $\sigma_{\varphi 3}$ are the standard errors of the coefficients $\varphi_{2}$ and $\varphi_{3}$ respectively. $\rho_{X 1}$ is the correlation between the independent and intervening variables. 
A third option is to examine the significance of the indirect effect through the product of the two coefficients $\varphi_{1}$ and $\varphi_{4}$ : in other words, the combined effect of the link from compulsory schoolbased enterprise education to voluntary enterprise education and that of voluntary enterprise education on entrepreneurial intentions or nascent entrepreneurship $\left(\varphi_{1} \varphi_{4}\right)$. Sobel (1982) gives the standard error of this as:

(5)

$$
\sigma_{\text {Sobel }}=\sqrt{\varphi_{1}^{2} \sigma_{\varphi 4}^{2}+\varphi_{4}^{2} \sigma_{\varphi 1}^{2}}
$$

The product of the coefficients is divided by this and a standard Z-test applied. Others suggest alternatives which incorporate the product of the two variances (Aroian, 1947; Goodman, 1960), but this usually has little impact on the results as this term is small. Based on simulations MacKinnon et al. (1998) suggest alternative critical values to those of the usual Z-test. MacKinnon et al. (2002) indicate that no test is without its potential problems, but suggest the product of coefficients test with adjusted critical values and the Freedman and Schatzkin (1992) difference of coefficients test have the most power. We use these tests along with the more widely used Baron and Kenny (1986), Kenny et al. (1998) and Sobel (1982) approaches. It is also true that any relationship between voluntary engagement with school-based enterprise education and entrepreneurial activities and attitudes is expected to operate in a similar manner with voluntary engagement in later stage entrepreneurial activity mediating this relationship. As noted in sections 1 to 3 , the emphasis in this study is not on the impact of voluntary engagement with school-based enterprise education, as increasing participation in such activities would be much harder, if not impossible, for policy to achieve. However, the equations to be estimated, as outlined above, will still capture such a relationship. For completeness we include tests of mediation of voluntary school-based enterprise education activities by later stage activities.

\section{Results}

The existing literature relating to school-based and later stage enterprise education was discussed in sections 2 and 3. Based on this prior work it appears that the most important role of school-based enterprise education is to encourage further engagement in additional training at later stages to generate sustained interest. Table 1 below presents the regressions based on equation 1 outlined in the preceding section, where the dependent variables are the later stage entrepreneurship education sources, and school-based enterprise education enters each of the specifications as an independent variable. The regressions only explain a limited amount of the deviation present, ranging from 2.7 percent in the formal work placements regression to 8.8 percent in the university regression. The likelihood ratio tests, however, indicate that the null of constant probability can be rejected, whilst the null of a good fit cannot be rejected.

\section{PLEASE INSERT TABLE 1 ABOUT HERE}

The main variable of interest within these regressions is that associated with compulsory schoolbased enterprise education. The coefficient, representing $\varphi_{1}$ in equation (1) outlined in the previous section, will be positive and significant if compulsory school-based enterprise education has a key role in generating sustained interest by encouraging later stage participation. It is also interesting to note the difference with the dummy representing those that voluntarily participated in enterprise education at school as this will reflect those who already had an interest in entrepreneurship and would be expected to go on to voluntarily engage with further enterprise education. 
The results suggest that, compared to those without enterprise education at school, those who undertook compulsory courses are significantly more likely to engage with university enterprise education and government training schemes. The impact is greatest when considering the probability of engaging with university education where compulsory school-based courses make respondents more than two and half times as likely to participate (odds ratio 2.714). However, this still compares to the self-selecting group who took school-based enterprise education on a voluntary basis who are six times as likely to follow this up at university (odds ratio 6.022). The influence of compulsory enterprise education at school on future participation in government training schemes is smaller. This is understandable as many of these will occur at a date more distant from the initial engagement, but still represents an almost doubling of the likelihood of future engagement with these courses (odds ratio 1.943). The results show that compulsory enterprise education at school has a substantial influence on the probability of individuals voluntarily engaging with enterprise education later in their educational and working careers in a variety of forms. The encouragement to engage with enterprise education at college or university is perhaps most valuable for both the individual and local economy. These educational/training schemes are likely to provide skills and knowledge that will be valuable regardless of whether those taking them choose to start their own business or move into employment within the public or private sector where the same skills are increasingly acknowledged as desirable (Binks et al., 2006; Rae, 2010). Given that after accounting for other influences, those exposed to compulsory enterprise education at school are almost three times as likely to engage further this is clearly a substantial effect. This shows the value of Government policies in recent years, which embed such teaching in the school curriculum (Gillie, 2012). Government training schemes however, may be more commonly focused on new venture creation (Henry et al., 2005). The near doubling of the probability of engaging with such schemes at a later date shows the potential for compulsory school-based enterprise education to not only generate interest during the duration of the course (Peterman and Kennedy, 2003; Man and Yu, 2007; Kwong et al., 2012b), but also to ensure that this interest is sustained over a longer period of time by encouraging participants to engage with further study.

There is less evidence of school-based enterprise education having an influence on participation in formal work placements, where the coefficient although positive is only weakly significant. This is potentially something that those designing and delivering enterprise education within schools may wish to address. Employers have regularly cited limited work experience and employability skills of young people as a barrier to their employment (Wilton, 2012). With SMEs accounting for 60 per cent of private sector employment in the UK in 2014 (Department for Business, Innovation and Skills, 2014), such work placements in SMEs would be expected to be valuable (Wilton, 2012). It would also provide further diversity of exposure, which promotes sustained interest (Barron, 2006).

The other factors that influence engagement with later stage courses include: gender, age, and being born outside the UK. Although considerable efforts have been made in the UK to encourage more women to start entrepreneurial careers, it is clear that engagement with associated courses still remains below the level found for men. Understandably the probability of engaging with later stage enterprise education increases with age and understandably beyond a certain point this probability will not increase given the need to retain sufficient time to recoup any investment in education. There is also evidence that immigrants entering a UK region from abroad are more likely to look to voluntarily engage with enterprise education courses at college or university and participate in formal work placements. Prior studies have suggested that this may be influenced by 
discrimination in the mainstream labour market (Jones, Mascarenhas-Keyes and Ram, 2012a), but may also in part due to a stronger tradition of small business ownership (Jones, Ram et al. 2012b).

Based in the existing literature covered in sections two and three it was suggested that compulsory school-based enterprise education may potentially influence engagement with entrepreneurial activities and careers although indirectly with this relationship mediated by voluntary engagement in later stage enterprise education. The results presented above suggest that indeed, compulsory school-based enterprise education has a substantial influence on the probability of engaging with later stage education and training schemes. As outlined in section four, the positive influence of compulsory enterprise education relies however, on these later stage sources of enterprise education having a positive impact on entrepreneurial activities.

Tables 2 to 4 below present the binary logistic regressions of entrepreneurial intentions (expecting to be involved in a business start in the next three years). These results examine the extent that compulsory school-based enterprise education has a direct influence on this particular manifestation of entrepreneurial attitudes and engagement with entrepreneurial activities as outlined by equation (2) in section four. This is captured by the coefficient on compulsory school based enterprise education in Model 1 in each table, representing $\varphi_{2}$ in equation (2). Model 2 in each table presents the regressions run including voluntary engagement with one of the three later stage sources of enterprise education (Table 2 - university based enterprise education; Table 3 - formal work placements; Table 4 - government training schemes), to capture the second part of the mediating relationship ( $\varphi_{4}$ in equation (3) in section 4 ). The lower panel of each table presents the results of the tests of a mediating relationship for the later stage enterprise education source of interest. Tables 2 to 4 present the full regression results with Table 5 providing a summary of the important coefficients outlined in the previous section and the whether the tests of a mediating relationship are significant.

As with the regressions of voluntary engagement with later stage enterprise education reported previously relatively low levels of deviation are explained, but the null of a good fit to the data cannot be rejected and the null of constant probability is rejected.

\section{PLEASE INSERT TABLE 2 ABOUT HERE}

In terms of entrepreneurial intentions compulsory enterprise education taken at school is positively associated with a greater probability of intending to start a business in the next two years when voluntary engagement with formal work placements (Table 3 ) and government training schemes (Table 4) are not included in the regressions ( $\varphi_{2}$ in equation (2)).

\section{PLEASE INSERT TABLE 3 ABOUT HERE \\ PLEASE INSERT TABLE 4 ABOUT HERE}

This is not the case for the university-based enterprise education regression (Table 2). Although compulsory engagement with university enterprise education is unlikely to be caused by schoolbased enterprise education, there is some correlation between the two, which reduces the significance of compulsory school-based enterprise education. Those that participate in compulsory enterprise education at school are approaching 20 to 30 percent more likely than those not taking enterprise education at school to indicate that they expect to be involved in a business start in the near future (odds ratios of 1.182 when controlling for compulsory university enterprise education 
and 1.297 when controlling for compulsory government training schemes). In contrast, those that take enterprise education at school on a voluntary basis are almost twice as likely as those taking no enterprise education at school to possess entrepreneurial intentions (odds ratio 1.883 when controlling for compulsory university enterprise education). All coefficients on compulsory schoolbased enterprise education are reduced and become insignificant when voluntary engagement with later stage enterprise education is added the regressions $\left(\varphi_{3}\right.$ in equation (3)). Although, voluntary engagement with school-based enterprise education remains a significant influence on the likelihood of an individual displaying entrepreneurial intention after the addition of voluntary engagement with all later stage sources of enterprise education, the coefficients decrease in size. This indicates that where pupils display an early interest in enterprise this may still be retained without renewal, but the later stage enterprise education voluntarily engaged in by many does appear to play a role in sustaining this interest.

The voluntary sources of enterprise education having the largest influence are university-based enterprise education (odds ratio 1.982), and government training schemes (odds ratio 2.202). These results have positive implications for initiatives at the school level. For those undertaking compulsory school-based enterprise education the results in Table 1 suggest engagement in these later stage activities is twice as likely for government training schemes and three times as likely for university courses. Once engaged with these later stage activities the probability of intending to start a business in the near future then approximately doubles. Bearing in mind that this is a very restricted measure of entrepreneurial intentions, which ignores intentions to work in a more entrepreneurial manner in waged employment, the benefits are likely to be considerable. It should, however, also be noted that the results above relate to the regressions run when using entrepreneurial intentions, which may not actually be realised in a large number of cases for a considerable time period, or at all (Kwong and Thompson, 2015). The formal work placements regressions show a similar positive relationship between voluntary engagement and entrepreneurial intentions although smaller (odds ratio 1.696). Given that compulsory enterprise education at school was only related to voluntary engagement in formal work placements at the 10 percent level it appears to have less influence through this mechanism. The test of the indirect effect $\left(\varphi_{1} \varphi_{4}\right)$ as proposed by Sobel (1982) confirms a mediating role for voluntary university enterprise education and government training schemes, but not for formal work placements. However, when using MacKinnon et al.'s (1998) adjusted critical values a mediated relationship is suggested for all three later stage enterprise education sources. The difference in coefficients $\left(\varphi_{2}-\varphi_{3}\right)$ proposed by Freedman and Schatzkin (1992) also suggests a mediating role for all three later stage enterprise education sources. Table 5 summarises the results which show consistent evidence of a mediating role for university based enterprise education and government training schemes, whilst the tests are more mixed in relation to formal work placements. The equivalent tests for voluntary engagement in school-based enterprise education suggest a mediating role for later stage enterprise education, including for formal work placements.

PLEASE INSERT TABLE 5 ABOUT HERE

Tables 6, 7 and 8 present the binary logistic regression results for nascent entrepreneurship (those actively starting a business at the time of the survey) when considering the mediating role of university based enterprise education, formal work placements and government training schemes respectively. 
A summary of the significance of the key coefficients and tests of mediation are outlined in Table 9. When considering the nascent entrepreneurship regressions summarised in Table 9, compulsory school-based enterprise education is not found to have a direct significant effect $\left(\varphi_{2}\right)$.

\section{PLEASE INSERT TABLE 9 ABOUT HERE}

As noted by MacKinnon et al. (2000) this could reflect the direct and indirect effects having opposite signs. Feasibly this might be the case where compulsory school-based enterprise education has a divisive effect on those exposed to it. Those positively influenced go on to later stage enterprise education, but for others they learn they are not suited/equipped for entrepreneurial careers, as Oosterbrook et al. (2010) found for Dutch university students. As Kenny et al. (1998) highlight, this means that the key results for the presence of mediation are the significance of coefficients $\varphi_{1}$ and $\varphi_{4}$ and a mediated relationship could still exist without a direct relationship existing, so that $\varphi_{2}$ need not be significant (MacKinnon et al., 2000).

The coefficients on compulsory school-based enterprise education all decreased in size when voluntary later stage enterprise education was included in the regression. As with entrepreneurial intentions Tables 6 and 8 show that voluntary engagement with university (odds ratio 1.731) and government supported (odds ratio 2.457) sources of enterprise education did increase the likelihood of being engaged in nascent entrepreneurship. The tests of a mediating relationship summarised in Table 9 confirm the presence of a link from compulsory school-based enterprise education to nascent entrepreneurship even with the absence of a significant direct relationship. Regardless of whether the standard test of the indirect effect (Sobel, 1982) or that with adjusted critical values (MacKinnon et al., 1998) was used, a mediating relationship was only found for voluntary engagement with university enterprise education and government training schemes. The difference in coefficients test did suggest a mediating relationship for all three sources. For voluntary engagement in school-based enterprise education later stage enterprise education from university and government sources appears to play a mediating role.

\section{Conclusion}

This article presents a novel theoretical approach to advance enterprise education research. Drawing upon theories of interest development from the field of educational science, it is argued that the role of enterprise education is beyond business start-up activity, or the provision of specific skill-sets to achieve this aim. Instead, within a context where the prospect and timing of starting a business is uncertain, creating a sustained and enduring interest, rather than a situational one, is crucial. It has been argued that there is a strong role for enterprise education in consolidating interest in entrepreneurial endeavours, by providing diverse, continuous and repetitive exposure. This should nurture the entrepreneurial spark of participants until they are ready, technically and mentally, to engage in entrepreneurial activities of all types. They will also become more willing to support others to do likewise and thereby contribute fully to an entrepreneurial society.

This study provides novel empirical evidence regarding the role of enterprise education in the development of sustained interest. The results show that compulsory school-based enterprise education has the potential to generate sustained interest in entrepreneurial activity. It does not 
directly influence entrepreneurial activity and attitudes, but instead operates through increased voluntary engagement with university-based enterprise education and government training schemes. Although the tests of mediation indicate some evidence of such a relationship for voluntary engagement with formal work placements, the results presented in Table 1 indicate that currently this mechanism appears to have less influence.

The results support calls from studies such as Vinten and Alcock (2004) and Thursby (2005), along with policymakers (Fagan, 2006), to embed enterprise in all stages of education and across all subjects. The literature on phases of interest development (Hidi and Renninger, 2006) also leads us to the view that in supporting an entrepreneur's journey, enterprise education works best when drawn from multiple sources working. This article has concentrated on compulsory school-based enterprise education as this is where policy is most likely to effectively ensure participation, but the results suggest that a similar causal chain is also present for those that voluntarily engage in schoolbased activities.

To extend from the theoretical paradigm of sustained interest, we propose a holistic framework of enterprise education where an overarching objective is to unify the currently fragmented enterprise education provision. Engaging in the various programmes at different stages would allow aspiring entrepreneurs to maintain their ambitions, and at the same time, further refine the technical skills and knowledge required to engage in all types of entrepreneurial activity (Henry et al., 2005). Coordination and cooperation between providers is important. A clear practical implication of the sustained interest paradigm is that schools, universities and governmental agencies should be responsible for working together to ensure that whilst school-based enterprise education encourages further study (Yu, 2013), expectations of what this future study will consist of are not inappropriate (von Graevenitz et al., 2010; Oosterbeek et al., 2010). Likewise, university courses need to continue the efforts of recent years to ensure that they do provide the skills, knowledge and confidence that budding entrepreneurs require (Piperopoulos and Dimov, 2014). This, however, is by no means an easy task - to integrate enterprise education components with existing curriculums, and achieve compatibility of learning, has already been found to be a challenge (Yu, 2013), but integrating and synchronising enterprise education provision at different levels produces an even greater challenge. The results indicate that such links will be important for both those whose interest was initiated by compulsory school-based enterprise education and those who voluntarily engaged due to a pre-existing interest. This may mean that those providing later stage courses have to consider whether there are different needs and requirements depending on where participant interest originates.

The study does have a number of limitations that future research would be advised to consider. First, with the existing dataset we can only use new venture creation as the final objective. This neglects the broader view of entrepreneurship that sees entrepreneurship as an essential basic skill that is useful regardless of whether someone is working for themselves or others. Further study exploring the effectiveness of the holistic approach would enhance our understanding of the way in which the different enterprise education programmes can come together to achieve a variety of outcomes. Second, the grouping of enterprise education into four broad groups does hide much variation. The content, form of delivery and duration of the courses are all important considerations (Piperopoulos and Dimov, 2014). Third, the study also limits itself to the situation in England and Wales. International comparisons where different styles of school-based enterprise education have been utilised would help establish best practice and enable courses to be optimised, although it would 
also be important to bear in mind the contextual factors that may make entrepreneurship more or less desirable for young people considering it as a career. Fourth, longitudinal work would be of considerable value in examining the underlying reasons why compulsory enterprise education at school acts as a gateway to some forms of later stage enterprise education, but not others, as was found to be the case for formal work placements in SMEs. Equally, those designing and delivering later stage enterprise education may have access to valuable information, such as opinions of students or training scheme participants, as to whether courses have met their expectations, and what role prior training had in forming these expectations. This relates closely to Oosterbeek et al.'s (2010) suggestions that enterprise education may have two effects, with the first on actual skills and the second on participant perceptions of skills. Participation in entrepreneurial activities will be influenced by both, but the balance of the two effects will determine the changes and modifications required for enterprise education at all levels. Finally, whilst we have concentrated on nascent entrepreneurship rates, more is not necessarily better, and it is important that studies also consider the quality of the new entrepreneurial ventures: will they survive; are they innovative, how many jobs will they create and ultimately, what is their value to society?

\section{Acknowledgements}

The authors would like to thank three anonymous referees for their comments and suggestions that greatly enhanced our work. We would also like to thank Professor Susan Marlow, whose guidance as editor in ensuring that the final version of the paper met the standards required, was greatly appreciated. Although the data used in this work are collected by the GEM consortium, their analysis and interpretation are the sole responsibility of the authors. Any remaining errors are the responsibility of the authors alone.

\section{References}

Ajzen I (1991) The theory of planned behaviour. Organizational Behavior and Human Decision Processes 50(2): 179-211.

Arenius P and De Clercq D (2005) Network-based approach on opportunity recognition. Small Business Economics 24(3): 249-265.

Aroian LA (1947) The probability function of the product of two normally distributed variables. Annals of Mathematical Statistics 18(2): 265-271.

Bae TJ, Qian S, Miao C and Fiet JO (2014) The relationship between entrepreneurship education and entrepreneurial intentions: a meta-analytic review. Entrepreneurship Theory and Practice 38(2): 217254.

Baker T, Gedajlovic E and Lubatkin M (2005) A framework for comparing entrepreneurship processes across nations. Journal of International Business Studies 36(5): 492-504.

Baron RM and Kenny DA (1986) The moderator-mediator variable distinction in social psychological research: conceptual, strategic and statistical considerations. Journal of Personality and Social Psychology 51(6): 1173-1182. 
Barron B (2006). Interest and self-sustained learning as catalysts of development: A learning ecology perspective. Human Development, 49(4), 193-224.

Baum JAC and Silverman BS (2004) Picking winners or building them? Alliance, intellectual, and human capital as selection criteria in venture financing and performance of biotechnology startups. Journal of Business Venturing 17(4): 411-436.

Beladi $\mathrm{H}$ and Kar S (2014) Unemployment benefits and entrepreneurship. Japanese Economic Review 65(1): 122-128.

BERR (2008) Unlocking the UK's Talent. BERR: London.

Binks M, Starkey $\mathrm{K}$ and Mahon CL (2006) Entrepreneurship education and the business school. Technology Analysis and Strategic Management 18(1): 1-18.

Block JH, Hoogerhide $L$ and Thurik R (2011) Education and entrepreneurial choice: an instrumental variables analysis. International Small Business Journal 31(1): 23-33.

Brooksbank DJ, Thompson P and Williams R (2008) Entrepreneurial attitudes, interactions and activities - a comparison of urban and rural areas in Wales. International Journal of Entrepreneurship and Small Business 6(3): 421-436.

Brush CG (1992) Research on women business owners: past trends, a new perspective and future directions. Entrepreneurship Theory and Practice 16(4): 5-30.

Bunten D, Weiler S, Thompson E and Zahran S (2014) Entrepreneurship, information, and growth. Journal of Regional Science, Epub ahead of print DOI: 10.1111/jors.12157

Caliendo M, Fossen FM and Kritikos AS (2009) Risk attitudes of nascent entrepreneurs - new evidence from an experimentally validated survey. Small Business Economics 32(2): 153-167.

Carsrud A and Brannback M (2011) Entrepreneurial motivation: what do we still need to know?. Journal of Small Business Management 49(1): 9-26.

Carter S, Mwaura S, Ram M, Trehan K and Jones T (2015) Barriers to ethnic minority and women's enterprise: existing evidence, policy tensions and unsettled questions. International Small Business Journal 33(1): 49-69.

Csikszentmihalyi M, Rathunde K \& Whalen S (1993). Talented teenagers: The roots of success and failure. New York: Cambridge University Press

Cheung C (2014) Innovative education and business engagement at the heart of entrepreneurial business schools. Journal of General Management, 40(1): 107-111.

Cohen J, Cohen P, West SG and Aiken LS (2003) Applied multiple regression/correlation analysis for the behavioural sciences: third edition. Mahwah, NJ: Lawrence Erlbaum Associates.

Delgado M, Porter ME and Stern S (2010) Clusters and entrepreneurship. Journal of Economic Geography 10(4): 495-518.

Dean KL \& Jolly JP (2012). Student identity, disengagement, and learning. Academy of Management Learning \& Education, 11(2): 228-243.

Delfmann H, Koster S, McCann P and van Dijk J (2014) Population change and new firm formation in urban and rural regions. Regional Studies 48(6): 1034-1050. 
Department for Business, Innovation and Skills (2014) Business Population Estimates for the UK and Regions 2014, Sheffield: Department for Business, Innovation and Skills.

Dickson PH, Solomon GT \& Weaver KM (2008). Entrepreneurial selection and success: does education matter?. Journal of small business and enterprise development, 15(2): 239-258.

Draycott M, Rae D and Vause $K$ (2011) The assessment of enterprise education in the secondary education sector: a new approach. Education + Training 53(8/9): 673-691.

Edelson DC, \& Joseph DM (2004). The interest-driven learning design framework: motivating learning through usefulness. In: Proceedings of the $6^{\text {th }}$ international conference on Learning sciences, pp. 166-173, 22-26 June. Santa Monica, CA: International Society of the Learning Sciences.

European Comission (2006) Entrepreneurship Education in Europe. Brussel: European Commission

Evans DS and Jovanovic B (1989) An estimated model of entrepreneurial choice under liquidity constraints. Journal of Political Economy 97(4): 808-827.

Fagan C (2006) Three Es for teachers: economics, enterprise and entrepreneurship. Teacher Development 10(3): 275-291.

Fairlie RW (2013) Entrepreneurship, economic conditions, and the Great Recession. Journal of Economics and Management Strategy 22(2): 207-231.

Fairlie RW and Krashinsky HA (2012) Liquidity constraints, household wealth, and entrepreneurship revisited. Review of Income and Wealth 58(2): 279-306.

Fayolle A, Gailly B and Lassas-Clerc N (2006) Assessing the impact of entrepreneurship education programmes: a new methodology. Journal of European Industrial Training 30(9): 701-720.

Fayolle A and Gailly B (2015) The Impact of entrepreneurship education on entrepreneurial attitudes and intention: hysteresis and persistence. Journal of Small Business Management 53(1): 75-93.

Fotopoulos G (2014) On the spatial stickiness of UK new firm formation rates. Journal of Economic Geography 14(3): 651-679.

Freeman LS and Schatzkin A (1992) Sample size for studying intermediate endpoints within intervention trials of observational studies. American Journal of Epidemiology 136(9): 1148-1159.

Freel MS (1999), "Policy, prediction and growth: picking winners?", Journal of Small Business and Enterprise Development, 5(1): 19-32.

Frenken K and Boschma RA (2007) A theoretical framework for evolutionary economic geography: industrial dynamics and urban growth as a branching process. Journal of Economic Geography 7(5): 635-649.

Gibb AA (1987). Enterprise culture-its meaning and implications for education and training. Journal of European Industrial Training, 11(2): 2-38.

Gicheva D and Link AN (2013) Leveraging entrepreneurship through private investments: does gender matter?. Small Business Economics 40(2): 199-210.

Gillie C (2012) Enterprise Education in Schools. London: House of Commons.

Goodman LA (1960) On the exact variance of products. Journal of the American Statistical Association 55(292): 708-713. 
Hannon P (2007) Enterprise for all? The fragility of enterprise provision across England's HEls. Journal of Small Business and Enterprise Development 14(2): 183-210.

Hayes JR (1985) Three problems in teaching general skills. In S.F. Chipman, J.W. Segal and R. Glaser (Eds.), Thinking and learning skills: Vol. 2. Research and open questions (pp.391-405). Hillsdale, NY: Erlbaum.

Henry C, Hill F and Leitch C (2005) The effectiveness of training for new business creation: a longitudinal study. International Small Business Journal 22(3): 249-271.

Hidi S and Renninger KA (2006) The four-phase model of interest development. Educational psychologist, 41(2): 111-127.

Jack SL and Anderson AR (2002) The effects of embeddedness on the entrepreneurial process. Journal of business Venturing, 17(5): 467-487.

Jaidi Y, van Hooft EAJ and Arends LR (2011) Recruiting highly educated graduates: a study on the relationship between recruitment information sources, the Theory of Planned Behavior, and actual job pursuit. Human Performance 24(2): 135-157.

Jones T, Mascarenhas-Keyes S and Ram M (2012a) The ethnic entrepreneurial transition: recent trends in British Indian self-employment. Journal of Ethnic and Migration Studies 38(1): 93-109.

Jones T, Ram M, Edwards P, Kiselinchev A and Muchenje L (2012b) New migrant enterprise: novelty or historical continuity?, Urban Studies 49(14): 3159-3176.

Jones-Evans D, Brooksbank D, Kwong C and Thompson P (2006) Enterprise training and entrepreneurial activity - evidence from the United Kingdom. In: RENT conference, Brussels, Belgium, 23-24 November.

Kalantaridis C and Bika Z (2006) In-migrant entrepreneurship in rural England: beyond local embeddedness. Entrepreneurship and Regional Development 18(2): 109-131.

Kautonen T, van Gelderen M and Tornikoski ET (2013) Predicting entrepreneurial behaviour: a test of the theory of planned behaviour. Applied Economics 45(6): 697-707.

Keat R (1991). Enterprise culture. Routledge:London.

Kenny DA, Kashy DA and Bolger N (1998) Data analysis in social psychology. In: Gilbert DT, Fiske ST and Lindzey G (eds) The Handbook of Social Psychology. Boston, MA: McGraw-Hill, pp. 233-265.

Kim G (2007) The analysis of self-employment levels over the life-cycle. Quarterly Review of Economics and Finance 47(3): 397-410.

Kirkpatrick DL (1959) Techniques for evaluating training programs. Journal of American Society for Training and Development 13(11): 3-9.

Klapper LF and Parker SC (2011) Gender and the business environment for new firm creation. World Bank Research Observer 26(2): 237-257.

Kourilsky ML (1995), Entrepreneurship Education: Opportunity in Search of Curriculum, Center for Entrepreneurial Leadership, Ewing Marion Kauffman Foundation, Kansas City, MO.

Kuratko DF (2005) The emergence of entrepreneurship education: development, trends, and challenges. Entrepreneurship Theory and Practice 29(5): 577-597. 
Kwong C and Thompson P (2015) The when and why: student entrepreneurial aspirations. Journal of Small Business Management. Epub ahead of print DOI: 10.1111/jsbm.12146

Kwong C, Jones-Evans D and Thompson P (2012a) Differences in perceptions of access to finance between potential male and female entrepreneurs: evidence from the UK. International Journal of Entrepreneurial Behaviour and Research 18(1): 75-97.

Kwong C, Thompson P and Cheung W (2012b) The effectiveness of social business plan competitions in developing social and civic awareness and participation. Academy of Management: Learning \& Education 11(3): 324-348.

Kwong C, Thompson P, Cheung W and Manzoor H (2012c) The role of environment in fostering conductive entrepreneurial learning - teaching the 'art' of entrepreneurship in summer boot camps. Journal of General Management 38(1): 45-72.

Ladson-Billings G (1995) But that's just good teaching! The case for culturally relevant pedagogy. Theory into practice, 34(3): 159-165.

Leinhardt G, Crowley K \& Knutson K. (Eds.). (2002). Learning conversations in museums. Taylor \& Francis: London.

Lévesque $M$ and Minniti M (2006) The effect of aging on entrepreneurial behaviour. Journal of Business Venturing 21(2): 177-194.

Levie JD (2007) Immigration, in-migration, ethnicity and entrepreneurship in the United Kingdom. Small Business Economics 28(2/3): 143-169.

Levie JD and Autio E (2008) A theoretical grounding and test of the GEM model. Small Business Economics 31(3): 235-263.

Lipstein R \& Renninger KA (2007) "Putting things into words": The development of 12-15-year-old students' interest for writing. In Boscolo, P. \& Hidi, S. (Eds.), Motivation and writing: Research and School Practice (pp. 113-140). New York: Elsevier.

Lofstrom M, Bates T and Parker SC (2014) Why are some people more likely to become smallbusinesses owners than others: entrepreneurial entry and industry-specific barriers. Journal of Business Venturing 29(2): 232-251.

Lourenço F, Jones O and Jayawarna D (2012) Promoting sustainable development: the role of entrepreneurship education. International Small Business Journal 31(8): 841-865.

MacKinnon DP, Krull JL and Lockwood CM (2000) Equivalence of the mediation, confounding, and suppression effect. Prevention Science, 1(4): 173-181.

MacKinnon DP, Lockwood CM and Hoffman JM (1998) A new method to test for mediation. In: Annual Meeting of the Society for Prevention Research, Park City, UT, June.

MacKinnon DP, Lockwood CM, Hoffman JM, West SG and Sheets V (2002) A comparison of methods to test mediation and other intervening variable effects. Psychological Methods 7(1): 83-104.

Mahlberg T (1996) Evaluating secondary school and college level entrepreneurial education - pilot testing a questionnaire. In: Internationalising Entrepreneurship Education and Training Conference, Arnhem, The Netherlands, 23-26 June. 
Man TWY and Yu CWM (2007) Social interaction and adolescent's learning in enterprise education: an empirical study. Education + Training 49(8/9): 620-633.

Marlow S and Patton D (2005) All credit to men? Entrepreneurship, finance, and gender. Entrepreneurship Theory and Practice 29(6): 717-735.

Martin BC, McNally J \& Kay MJ (2013). Examining the formation of human capital in entrepreneurship: A meta-analysis of entrepreneurship education outcomes. Journal of Business Venturing, 28(2): 211-224.

McLarty L, Highley H and Alderson S (2010) Evaluation of Enterprise Education in England. Research Report for The Department for Education. Report no. DFE-RR015, Leeds: Dubit.

Morris MH, Webb JW, Fu J \& Singhal S (2013) A Competency - Based Perspective on Entrepreneurship Education: Conceptual and Empirical Insights. Journal of Small Business Management, 51(3): 352-369.

Mueller SL and Conway Data-on M (2013) A cross cultural study of gender-role orientation and entrepreneurial self-efficacy. International Entrepreneurship and Management Journal 9(1): 120.Office for National Statistics (2004) Rural and Urban Classification 2004. London: HMSO.

Ofsted (2011) Economics, business and enterprise education. Manchester: Ofsted.

Oosterbeek H, van Praag M and ljsselstein A (2010) The impact of entrepreneurship education on entrepreneurship skills and motivation. European Economic Review 54(3): 442-454.

Peterman NE and Kennedy J (2003) Enterprise education: influencing students' perceptions of entrepreneurship. Entrepreneurship Theory and Practice 28(2): 129-144.

Pickernell D, Packham G, Jones P, Miller C and Thomas B (2011) Graduate entrepreneurs are different: they have more knowledge?. International Journal of Entrepreneurial Behaviour and Research 17(2): 183-202.

Piperopoulos P and Dimov D (2014) Burst bubbles or build steam? Entrepreneurship education, entrepreneurial self-efficacy, and entrepreneurial intentions. Journal of Small Business Management Epub ahead of print DOI: 10.1111/jsbm.12116

Rae D (2010) Universities and enterprise education: responding to the challenges of the new era. Journal of Small Business and Enterprise Development 17(4): 591-606.

Rasmussen E, Mosey S \& Wright M (2011) The evolution of entrepreneurial competencies: A longitudinal study of university spin - off venture emergence. Journal of Management Studies, 48(6): 1314-1345.

Renninger KA (2000). Individual Interest and its Implications for Understanding Intrinsic Motivation. In C. Sansone and J.M. Harackiewicz (eds) Intrinsic Motivation: Controversies and New Directions, 373-404. San Diego, CA: Academic Press.

Renninger K and Hidi S (2002) Student interest and achievement: Developmental issues raised by a case study. In: Wigfield A and Eccles J (eds) Development of Achievement Motivation. San Diego, CA: Academic Press, pp. 173-195.

Renninger KA \& Shumar W (2002) Building virtual communities: Learning and change in cyberspace. Cambridge University Press. 
Reynolds PD, Bosma N, Autio E, Hunt S, De Bono D, Servais I, Lopez-Garcia L and Chin N (2005) Global Entrepreneurship Monitor: data collection design and implementation 1998-2003. Small Business Economics 24(3): 205-231.

Rideout EC and Gray DO (2013) Does entrepreneurship education really work? A review and methodological critique of the empirical literature on the effects of university-based entrepreneurship education. Journal of Small Business Management 51(3): 329-351.

Ritsilä J and Tervo H (2002) Effects of unemployment on new firm formation: micro-level panel data evidence from Finland. Small Business Economics 19(1): 31-40.

Shane S (2008) The Illusions of Entrepreneurship: The Costly Myths that Entrepreneurs, Investors, and Policy Makers Live By. New Haven, CT: Yale University Press.

Shane S and Venkataraman S (2000) The promise of entrepreneurship as a field of research. Academy of Management Review 25(1): 217-226.

Shapero A and Sokol L (1982) Social dimension of entrepreneurship. In Kent C, Sexton D and Vesper K (eds) The Encyclopedia of Entrepreneurship. Englewood Cliffs, NJ: Prentice-Hall, pp. 72-90.

Sobel ME (1982) Asymptotic confidence intervals for indirect effects in structural equation models. Sociological Methodology 13: 290-312.

Solomon G (2007) An examination of entrepreneurship education in the United States. Journal of Small Business and Enterprise Development 14(2): 168-182.

Thursby MC (2005) Introducing technology entrepreneurship to graduate education: an integrative approach. Advances in the Study of Entrepreneurship, Innovation and Economic Growth 16: 211-240.

Van Gelderen M, Brand M, van Praag M, Bodewes W, Poutsma E and van Gils A (2008) Explaining entrepreneurial intentions by means of the theory of planned behaviour. Career Development International 13(6): 538-559.

Vesper KH (1988) Entrepreneurship: today courses, tomorrow degrees?. Entrepreneurship Theory and Practice 13(1): 7-13.

Vesper KH and Gartner WB (1997) Measuring progress in entrepreneurship education. Journal of Business Venturing 12(5): 403-421.

Vinten $\mathrm{G}$ and Alcock S (2004) Entrepreneuring in education. International Journal of Educational Management 18(3): 188-195.

Volery T, Muller S, Oser F, Naepflin C \& Rey N (2013). The Impact of Entrepreneurship Education on Human Capital at Upper - Secondary Level. Journal of Small Business Management, 51(3): 429-446.

von Graenvenitz G, Harhoff D and Weber R (2010) The effects of entrepreneurship education. Journal of Economic Behavior and Organization 76(1): 90-112.

Wilton N (2012) The impact of work placements on skills development and career outcomes for business and management graduates. Studies in Higher Education 37(5), 603-620.

Yu CMW (2013) Capacity building to advance entrepreneurship education: lessons from the teen entrepreneurship competition in Hong Kong. Education + Training 55(7): 705-718. 
Table 1 - Binary logistic regressions of later sources of enterprise education and the influence of compulsory school based enterprise education

\begin{tabular}{|c|c|c|c|c|}
\hline Dependent Variable & & $\begin{array}{c}\text { University } \\
\text { Based }\end{array}$ & $\begin{array}{l}\text { Formal Work } \\
\text { Placements }\end{array}$ & $\begin{array}{l}\text { Government } \\
\text { Training } \\
\text { Schemes } \\
\end{array}$ \\
\hline \multirow{2}{*}{$\begin{array}{l}\text { Participation in School } \\
\text { Based Enterprise Education } \\
\text { (base category no } \\
\text { participation) }\end{array}$} & $\begin{array}{l}\text { Compulsory } \\
\qquad\left(\varphi_{1}\right)\end{array}$ & $\begin{array}{l}0.9985 \\
(0.000)\end{array}$ & $\begin{array}{l}0.1777 \\
(0.060)\end{array}$ & $\begin{array}{l}\mathbf{0 . 6 6 4 2} \\
(0.000)\end{array}$ \\
\hline & Voluntary & $\begin{array}{l}1.7953 \\
(0.000)\end{array}$ & $\begin{array}{l}0.9399 \\
(0.000)\end{array}$ & $\begin{array}{l}1.1412 \\
(0.000)\end{array}$ \\
\hline Gender & Male & $\begin{array}{l}\mathbf{0 . 2 4 8 1} \\
(0.000)\end{array}$ & $\begin{array}{l}\mathbf{0 . 4 0 3 2} \\
(0.000)\end{array}$ & $\begin{array}{l}\mathbf{0 . 1 6 0 7} \\
(0.005)\end{array}$ \\
\hline \multirow{3}{*}{ Human Capital } & Age & $\begin{array}{l}0.0292 \\
(0.383)\end{array}$ & $\begin{array}{l}\mathbf{0 . 0 5 6 5} \\
(0.050)\end{array}$ & $\begin{array}{l}\mathbf{0 . 1 4 0 9} \\
(0.000)\end{array}$ \\
\hline & $\mathrm{Age}^{2}$ & $\begin{array}{l}-0.0378 \\
(0.461)\end{array}$ & $\begin{array}{l}-0.0950 \\
(0.031)\end{array}$ & $\begin{array}{l}-0.1654 \\
(0.005)\end{array}$ \\
\hline & $\begin{array}{l}\text { University } \\
\text { Graduate }\end{array}$ & $\begin{array}{l}0.3148 \\
(0.000)\end{array}$ & $\begin{array}{l}0.0009 \\
(0.985)\end{array}$ & $\begin{array}{r}-0.0360 \\
(0.553)\end{array}$ \\
\hline \multirow{5}{*}{$\begin{array}{l}\text { Workstatus (base category } \\
\text { Full-Time Employed) }\end{array}$} & $\begin{array}{l}\text { Part Time } \\
\text { Employed }\end{array}$ & $\begin{array}{l}-0.1153 \\
(0.104)\end{array}$ & $\begin{array}{l}0.0919 \\
(0.120)\end{array}$ & $\begin{array}{l}-0.0819 \\
(0.276)\end{array}$ \\
\hline & $\begin{array}{l}\text { Out of Work } \\
\text { Force }\end{array}$ & $\begin{array}{r}-0.1033 \\
(0.272)\end{array}$ & $\begin{array}{l}0.2950 \\
(0.000)\end{array}$ & $\begin{array}{r}-0.1212 \\
(0.218)\end{array}$ \\
\hline & Student & $\begin{array}{l}0.1345 \\
(0.306)\end{array}$ & $\begin{array}{l}0.0551 \\
(0.638)\end{array}$ & $\begin{array}{l}-0.3459 \\
(0.060)\end{array}$ \\
\hline & Unemployed & $\begin{array}{l}0.0169 \\
(0.916)\end{array}$ & $\begin{array}{l}-0.0186 \\
(0.888)\end{array}$ & $\begin{array}{l}0.1166 \\
(0.464)\end{array}$ \\
\hline & $\begin{array}{l}\text { Economically } \\
\text { Inactive }\end{array}$ & $\begin{array}{l}0.2807 \\
(0.101)\end{array}$ & $\begin{array}{l}-0.0061 \\
(0.969)\end{array}$ & $\begin{array}{r}-0.0868 \\
(0.683)\end{array}$ \\
\hline \multirow{2}{*}{$\begin{array}{c}\text { Household Income (base } \\
\text { category } £ 17,500 \text { - } \\
£ 49,999)\end{array}$} & Under $£ 17,500$ & $\begin{array}{r}-0.0849 \\
(0.204)\end{array}$ & $\begin{array}{l}0.0040 \\
(0.941)\end{array}$ & $\begin{array}{l}-0.0210 \\
(0.764)\end{array}$ \\
\hline & $£ 50,000$ or more & $\begin{array}{l}0.2196 \\
(0.000)\end{array}$ & $\begin{array}{l}0.0374 \\
(0.487)\end{array}$ & $\begin{array}{l}-0.0454 \\
(0.511)\end{array}$ \\
\hline \multirow{2}{*}{$\begin{array}{l}\text { Migration Status (base } \\
\text { category Life-Long } \\
\text { Residents) }\end{array}$} & In-Migrants & $\begin{array}{l}-0.0698 \\
(0.198)\end{array}$ & $\begin{array}{l}0.0108 \\
(0.814)\end{array}$ & $\begin{array}{l}-0.0499 \\
(0.391)\end{array}$ \\
\hline & Immigrants & $\begin{array}{l}0.3450 \\
(0.000)\end{array}$ & $\begin{array}{l}0.3209 \\
(0.000)\end{array}$ & $\begin{array}{l}0.0373 \\
(0.690)\end{array}$ \\
\hline \multirow{3}{*}{ Environmental Influences } & $\begin{array}{l}\text { Local Authority } \\
\text { Unemployment }\end{array}$ & $\begin{array}{l}0.0412 \\
(0.197)\end{array}$ & $\begin{array}{l}-0.0364 \\
(0.185)\end{array}$ & $\begin{array}{l}0.0654 \\
(0.061)\end{array}$ \\
\hline & Urban & $\begin{array}{r}-0.1700 \\
(0.003)\end{array}$ & $\begin{array}{l}-0.0029 \\
(0.954)\end{array}$ & $\begin{array}{r}-0.0422 \\
(0.499)\end{array}$ \\
\hline & Constant & $\begin{array}{l}-2.9381 \\
(0.000)\end{array}$ & $\begin{array}{l}-2.3802 \\
(0.000)\end{array}$ & $\begin{array}{l}-5.3371 \\
(0.000)\end{array}$ \\
\hline
\end{tabular}

Notes: $\mathrm{p}$-values in parenthesis; emboldened values are significant at the 5 percent level 
Table 1 - Continued

\begin{tabular}{cccc}
\hline Dependent Variable & $\begin{array}{c}\text { University } \\
\text { Based }\end{array}$ & $\begin{array}{c}\text { Formal Work } \\
\text { Placements }\end{array}$ & $\begin{array}{c}\text { Government } \\
\text { Training } \\
\text { Schemes }\end{array}$ \\
\hline$R^{2}$ & 16,343 & 16,343 & 16,343 \\
Percentage Correct & 0.088 & 0.027 & 0.030 \\
Hosmer-Lemeshow Test & 86.4 & 81.0 & 89.6 \\
& 10.12 & 14.87 & 13.93 \\
& $(0.257)$ & $(0.062)$ & $(0.084)$ \\
LR test (null of constant probability) & 1160.1 & 427.4 & 330.3 \\
& {$[27]$} & {$[27]$} & {$[27]$} \\
& $(0.000)$ & $(0.000)$ & $(0.000)$ \\
\hline Notes: $p$-values in parenthesis; emboldened values are significant at the 5 percent
\end{tabular}

Notes: $p$-values in parenthesis; emboldened values are significant at the 5 percent level 
Table 2 - Binary logistic regressions of entrepreneurial intentions and the mediating influence of university based enterprise education (controlling for compulsory engagement)

\begin{tabular}{|c|c|c|c|}
\hline & & $\begin{array}{c}\text { Model } 1 \\
\text { No Control for } \\
\text { Voluntary Engagement } \\
\text { in Later Stage } \\
\text { Enterprise Education } \\
\end{array}$ & $\begin{array}{c}\text { Model } 2 \\
\text { Controls for Voluntary } \\
\text { Engagement in Later } \\
\text { Stage Enterprise } \\
\text { Education }\end{array}$ \\
\hline \multicolumn{4}{|l|}{$\begin{array}{l}\text { Participation in } \\
\text { Enterprise } \\
\text { Education (base } \\
\text { category no } \\
\text { participation) }\end{array}$} \\
\hline \multirow{2}{*}{ School Based } & $\begin{array}{l}\text { Compulsory } \\
\left(\varphi_{2} \text { and } \varphi_{3}\right)\end{array}$ & $\begin{array}{l}0.1676 \\
(0.185)\end{array}$ & $\begin{array}{l}0.0357 \\
(0.779)\end{array}$ \\
\hline & Voluntary & $\begin{array}{l}\mathbf{0 . 6 3 3 1} \\
(0.000)\end{array}$ & $\begin{array}{l}0.3969 \\
(0.000)\end{array}$ \\
\hline \multirow{2}{*}{ University Based } & Compulsory & $\begin{array}{l}0.5155 \\
(0.000)\end{array}$ & $\begin{array}{l}\mathbf{0 . 7 0 9 8} \\
(0.000)\end{array}$ \\
\hline & $\begin{array}{c}\text { Voluntary } \\
\left(\varphi_{4}\right)\end{array}$ & & $\begin{array}{l}\mathbf{0 . 6 8 4 0} \\
(0.000)\end{array}$ \\
\hline Gender & Male & $\begin{array}{l}\mathbf{0 . 8 3 1 9} \\
(0.000)\end{array}$ & $\begin{array}{l}\mathbf{0 . 8 0 7 4} \\
(0.000)\end{array}$ \\
\hline \multirow{3}{*}{ Human Capital } & Age & $\begin{array}{l}0.0547 \\
(0.171)\end{array}$ & $\begin{array}{l}0.0523 \\
(0.193)\end{array}$ \\
\hline & $\mathrm{Age}^{2}$ & $\begin{array}{c}-0.0981 \\
(0.109)\end{array}$ & $\begin{array}{r}-0.0950 \\
(0.122)\end{array}$ \\
\hline & University Graduate & $\begin{array}{l}0.1986 \\
(0.002)\end{array}$ & $\begin{array}{l}\mathbf{0 . 1 5 7 2} \\
(0.015)\end{array}$ \\
\hline \multirow{5}{*}{$\begin{array}{l}\text { Workstatus } \\
\text { (base category } \\
\text { Full-Time } \\
\text { Employed) }\end{array}$} & Part Time Employed & $\begin{array}{l}\mathbf{0 . 3 5 3 4} \\
(0.000)\end{array}$ & $\begin{array}{l}\mathbf{0 . 3 6 3 1} \\
(0.000)\end{array}$ \\
\hline & Out of Work Force & $\begin{array}{l}\mathbf{0 . 3 0 6 3} \\
(0.006)\end{array}$ & $\begin{array}{l}\mathbf{0 . 3 1 1 8} \\
(0.005)\end{array}$ \\
\hline & Student & $\begin{array}{l}0.2142 \\
(0.169)\end{array}$ & $\begin{array}{l}0.1944 \\
(0.215)\end{array}$ \\
\hline & Unemployed & $\begin{array}{l}0.9243 \\
(0.000)\end{array}$ & $\begin{array}{l}0.9263 \\
(0.000)\end{array}$ \\
\hline & Economically Inactive & $\begin{array}{l}0.9740 \\
(0.000)\end{array}$ & $\begin{array}{l}0.9582 \\
(0.000)\end{array}$ \\
\hline
\end{tabular}

Notes: $p$-values in parenthesis; emboldened values are significant at the 5 percent level 
Table 2 - continued

\begin{tabular}{|c|c|c|c|}
\hline & & $\begin{array}{c}\text { Model } 1 \\
\text { No Control for } \\
\text { Voluntary Engagement } \\
\text { in Later Stage } \\
\text { Enterprise Education }\end{array}$ & $\begin{array}{c}\text { Model } 2 \\
\text { Controls for Voluntary } \\
\text { Engagement in Later } \\
\text { Stage Enterprise } \\
\text { Education }\end{array}$ \\
\hline \multirow{2}{*}{$\begin{array}{l}\text { Household } \\
\text { Income (base } \\
\text { category } \\
£ 17,500 \text { - } \\
£ 49,999 \text { ) }\end{array}$} & Under $£ 17,500$ & $\begin{array}{l}-0.0424 \\
(0.584)\end{array}$ & $\begin{array}{l}-0.0408 \\
(0.600)\end{array}$ \\
\hline & $£ 50,000$ or more & $\begin{array}{l}0.1211 \\
(0.096)\end{array}$ & $\begin{array}{l}0.0967 \\
(0.186)\end{array}$ \\
\hline \multirow{2}{*}{$\begin{array}{l}\text { Migration Status } \\
\text { (base category } \\
\text { Life-Long } \\
\text { Residents) }\end{array}$} & In-Migrants & $\begin{array}{l}0.2402 \\
(0.000)\end{array}$ & $\begin{array}{l}0.2523 \\
(0.000)\end{array}$ \\
\hline & Immigrants & $\begin{array}{l}0.7978 \\
(0.000)\end{array}$ & $\begin{array}{l}0.7603 \\
(0.000)\end{array}$ \\
\hline \multirow{2}{*}{$\begin{array}{l}\text { Environmental } \\
\text { Influences }\end{array}$} & LA Unemployment & $\begin{array}{r}-0.0117 \\
(0.758)\end{array}$ & $\begin{array}{r}-0.0141 \\
(0.711)\end{array}$ \\
\hline & Urban & $\begin{array}{l}-0.1144 \\
(0.103)\end{array}$ & $\begin{array}{l}-0.0982 \\
(0.163)\end{array}$ \\
\hline & Constant & $\begin{array}{r}-3.4866 \\
(0.000)\end{array}$ & $\begin{array}{l}-3.5165 \\
(0.000)\end{array}$ \\
\hline & $N$ & 16,343 & 16,343 \\
\hline & $R^{2}$ & 0.061 & 0.069 \\
\hline Perce & age Correct & 91.2 & 91.2 \\
\hline \multicolumn{2}{|c|}{ Hosmer-Lemeshow Test } & $\begin{array}{c}8.94 \\
(0.347)\end{array}$ & $\begin{array}{c}9.89 \\
(0.273)\end{array}$ \\
\hline \multicolumn{2}{|c|}{ LR test (null of constant probability) } & $\begin{array}{c}594.3 \\
{[28]} \\
(0.000)\end{array}$ & $\begin{array}{c}676.2 \\
{[29]} \\
(0.000)\end{array}$ \\
\hline \multicolumn{4}{|c|}{$\frac{\text { Mediation Tests - Compulsory School }}{\text { Based }}$} \\
\hline \multicolumn{3}{|c|}{ Sobel (1982) Test of Product of Coefficients } & $\begin{array}{c}7.104 \\
(0.000)\end{array}$ \\
\hline \multicolumn{2}{|c|}{$\begin{array}{l}\text { MacKinnon et al. (1998) Test of Product of } \\
\text { Coefficients }\end{array}$} & & $\begin{array}{c}7.104 \\
(0.000)\end{array}$ \\
\hline \multicolumn{2}{|c|}{$\begin{array}{l}\text { Freedman and Schatzkin (1992) Test of } \\
\text { Difference in Coefficients }\end{array}$} & & $\begin{array}{l}15.421 \\
(0.000)\end{array}$ \\
\hline \multicolumn{4}{|c|}{ Mediation Tests - Voluntary School Based } \\
\hline \multicolumn{2}{|c|}{ Sobel (1982) Test of Product of Coefficients } & & $\begin{array}{c}8.931 \\
(0.000)\end{array}$ \\
\hline \multicolumn{2}{|c|}{$\begin{array}{l}\text { MacKinnon et al. (1998) Test of Product of } \\
\text { Coefficients }\end{array}$} & & $\begin{array}{c}8.931 \\
(0.000)\end{array}$ \\
\hline $\begin{array}{l}\text { Freedman and } \\
\text { Differen }\end{array}$ & $\begin{array}{l}\text { hatzkin (1992) Test of } \\
\text { in Coefficients }\end{array}$ & & $\begin{array}{l}10.529 \\
(0.000)\end{array}$ \\
\hline
\end{tabular}

Notes: p-values in parenthesis; emboldened values are significant at the 5 percent level 
Table 3 - Binary logistic regressions of entrepreneurial intentions and the mediating influence of formal work placements (controlling for compulsory engagement)

\begin{tabular}{|c|c|c|c|}
\hline & & $\begin{array}{c}\text { Model } 1 \\
\text { No Control for } \\
\text { Voluntary Engagement } \\
\text { in Later Stage } \\
\text { Enterprise Education } \\
\end{array}$ & $\begin{array}{c}\text { Model } 2 \\
\text { Controls for Voluntary } \\
\text { Engagement in Later } \\
\text { Stage Enterprise } \\
\text { Education }\end{array}$ \\
\hline \multicolumn{4}{|l|}{$\begin{array}{l}\text { Participation in } \\
\text { Enterprise } \\
\text { Education (base } \\
\text { category no } \\
\text { participation) }\end{array}$} \\
\hline \multirow{2}{*}{ School Based } & $\begin{array}{l}\text { Compulsory } \\
\left.\text { ( } \varphi_{2} \text { and } \varphi_{3}\right)\end{array}$ & $\begin{array}{l}0.2495 \\
(0.044)\end{array}$ & $\begin{array}{l}0.1933 \\
(0.121)\end{array}$ \\
\hline & Voluntary & $\begin{array}{l}0.6423 \\
(0.000)\end{array}$ & $\begin{array}{l}\mathbf{0 . 5 4 2 7} \\
(0.000)\end{array}$ \\
\hline \multirow{2}{*}{$\begin{array}{l}\text { Formal Work } \\
\text { Placements }\end{array}$} & Compulsory & $\begin{array}{l}0.1094 \\
(0.095)\end{array}$ & $\begin{array}{l}0.3084 \\
(0.000)\end{array}$ \\
\hline & $\begin{array}{c}\text { Voluntary } \\
\left(\varphi_{4}\right)\end{array}$ & & $\begin{array}{l}0.5284 \\
(0.000)\end{array}$ \\
\hline Gender & Male & $\begin{array}{l}0.8465 \\
(0.000)\end{array}$ & $\begin{array}{l}\mathbf{0 . 8 2 0 7} \\
(0.000)\end{array}$ \\
\hline \multirow{3}{*}{ Human Capital } & Age & $\begin{array}{l}0.0540 \\
(0.176)\end{array}$ & $\begin{array}{l}0.0469 \\
(0.241)\end{array}$ \\
\hline & $\mathrm{Age}^{2}$ & $\begin{array}{l}-0.0953 \\
(0.119)\end{array}$ & $\begin{array}{r}-0.0789 \\
(0.199)\end{array}$ \\
\hline & University Graduate & $\begin{array}{l}0.2234 \\
(0.000)\end{array}$ & $\begin{array}{l}0.2175 \\
(0.001)\end{array}$ \\
\hline \multirow{5}{*}{$\begin{array}{l}\text { Workstatus } \\
\text { (base category } \\
\text { Full-Time } \\
\text { Employed) }\end{array}$} & Part Time Employed & $\begin{array}{l}\mathbf{0 . 3 5 1 6} \\
(0.000)\end{array}$ & $\begin{array}{l}\mathbf{0 . 3 4 2 8} \\
(0.000)\end{array}$ \\
\hline & Out of Work Force & $\begin{array}{l}0.3118 \\
(0.005)\end{array}$ & $\begin{array}{l}0.2922 \\
(0.009)\end{array}$ \\
\hline & Student & $\begin{array}{l}0.2066 \\
(0.184)\end{array}$ & $\begin{array}{l}0.2051 \\
(0.188)\end{array}$ \\
\hline & Unemployed & $\begin{array}{l}0.9086 \\
(0.000)\end{array}$ & $\begin{array}{l}0.9205 \\
(0.000)\end{array}$ \\
\hline & Economically Inactive & $\begin{array}{l}0.9668 \\
(0.000)\end{array}$ & $\begin{array}{l}0.9742 \\
(0.000)\end{array}$ \\
\hline
\end{tabular}

Notes: p-values in parenthesis; emboldened values are significant at the 5 percent level 
Table 3 - continued

\begin{tabular}{|c|c|c|c|}
\hline & & $\begin{array}{c}\text { Model } 1 \\
\text { No Control for } \\
\text { Voluntary Engagement } \\
\text { in Later Stage } \\
\text { Enterprise Education }\end{array}$ & $\begin{array}{c}\text { Model } 2 \\
\text { Controls for Voluntary } \\
\text { Engagement in Later } \\
\text { Stage Enterprise } \\
\text { Education }\end{array}$ \\
\hline \multirow{2}{*}{$\begin{array}{l}\text { Household } \\
\text { Income (base } \\
\text { category } \\
£ 17,500 \text { - } \\
£ 49,999 \text { ) }\end{array}$} & Under $£ 17,500$ & $\begin{array}{c}-0.0388 \\
(0.617)\end{array}$ & $\begin{array}{l}-0.0412 \\
(0.595)\end{array}$ \\
\hline & $£ 50,000$ or more & $\begin{array}{l}0.1225 \\
(0.092)\end{array}$ & $\begin{array}{l}0.1232 \\
(0.091)\end{array}$ \\
\hline \multirow{2}{*}{$\begin{array}{l}\text { Migration Status } \\
\text { (base category } \\
\text { Life-Long } \\
\text { Residents) }\end{array}$} & In-Migrants & $\begin{array}{l}\mathbf{0 . 2 4 4 0} \\
(0.000)\end{array}$ & $\begin{array}{l}\mathbf{0 . 2 4 7 2} \\
(0.000)\end{array}$ \\
\hline & Immigrants & $\begin{array}{l}0.8197 \\
(0.000)\end{array}$ & $\begin{array}{l}0.8170 \\
(0.000)\end{array}$ \\
\hline \multirow{2}{*}{$\begin{array}{l}\text { Environmental } \\
\text { Influences }\end{array}$} & LA Unemployment & $\begin{array}{r}-0.0145 \\
(0.702)\end{array}$ & $\begin{array}{r}-0.0117 \\
(0.757)\end{array}$ \\
\hline & Urban & $\begin{array}{l}-0.1153 \\
(0.100)\end{array}$ & $\begin{array}{l}-0.1099 \\
(0.118)\end{array}$ \\
\hline & Constant & $\begin{array}{r}-3.5110 \\
(0.000)\end{array}$ & $\begin{array}{l}-3.6328 \\
(0.000)\end{array}$ \\
\hline & $N$ & 16,343 & 16,343 \\
\hline & $R^{2}$ & 0.059 & 0.065 \\
\hline Perce & age Correct & 91.2 & 91.2 \\
\hline \multicolumn{2}{|c|}{ Hosmer-Lemeshow Test } & $\begin{array}{c}9.56 \\
(0.297)\end{array}$ & $\begin{array}{c}5.31 \\
(0.724)\end{array}$ \\
\hline \multicolumn{2}{|c|}{ LR test (null of constant probability) } & $\begin{array}{c}576.8 \\
{[28]} \\
(0.000)\end{array}$ & $\begin{array}{c}630.0 \\
{[29]} \\
(0.000)\end{array}$ \\
\hline \multicolumn{4}{|c|}{$\frac{\text { Mediation Tests - Compulsory School }}{\text { Based }}$} \\
\hline \multicolumn{3}{|c|}{ Sobel (1982) Test of Product of Coefficients } & $\begin{array}{c}1.821 \\
(0.076)\end{array}$ \\
\hline \multicolumn{2}{|c|}{$\begin{array}{l}\text { MacKinnon et al. (1998) Test of Product of } \\
\text { Coefficients }\end{array}$} & & $\begin{array}{c}1.821 \\
(0.000)\end{array}$ \\
\hline \multicolumn{2}{|c|}{$\begin{array}{l}\text { Freedman and Schatzkin (1992) Test of } \\
\text { Difference in Coefficients }\end{array}$} & & $\begin{array}{l}58.077 \\
(0.000)\end{array}$ \\
\hline \multicolumn{4}{|c|}{ Mediation Tests - Voluntary School Based } \\
\hline \multicolumn{2}{|c|}{ Sobel (1982) Test of Product of Coefficients } & & $\begin{array}{c}6.730 \\
(0.000)\end{array}$ \\
\hline \multicolumn{2}{|c|}{$\begin{array}{c}\text { Mackinnon et al. (1998) Test of Product of } \\
\text { Coefficients }\end{array}$} & & $\begin{array}{c}6.730 \\
(0.000)\end{array}$ \\
\hline $\begin{array}{l}\text { Freedman and } \\
\text { Differen }\end{array}$ & $\begin{array}{l}\text { hatzkin (1992) Test of } \\
\text { in Coefficients }\end{array}$ & & $\begin{array}{l}8.840 \\
(0.000)\end{array}$ \\
\hline
\end{tabular}

Notes: p-values in parenthesis; emboldened values are significant at the 5 percent level 
Table 4 - Binary logistic regressions of entrepreneurial intentions and the mediating influence of government training schemes (controlling for compulsory engagement)

\begin{tabular}{|c|c|c|c|}
\hline & & $\begin{array}{c}\text { Model } 1 \\
\text { No Control for } \\
\text { Voluntary Engagement } \\
\text { in Later Stage } \\
\text { Enterprise Education } \\
\end{array}$ & $\begin{array}{c}\text { Model } 2 \\
\text { Controls for Voluntary } \\
\text { Engagement in Later } \\
\text { Stage Enterprise } \\
\text { Education }\end{array}$ \\
\hline \multicolumn{4}{|l|}{$\begin{array}{l}\text { Participation in } \\
\text { Enterprise } \\
\text { Education (base } \\
\text { category no } \\
\text { participation) }\end{array}$} \\
\hline \multirow{2}{*}{ School Based } & $\begin{array}{l}\text { Compulsory } \\
\left(\varphi_{2} \text { and } \varphi_{3}\right)\end{array}$ & $\begin{array}{l}0.2602 \\
(0.035)\end{array}$ & $\begin{array}{l}0.1971 \\
(0.113)\end{array}$ \\
\hline & Voluntary & $\begin{array}{l}\mathbf{0 . 6 4 4 4} \\
(0.000)\end{array}$ & $\begin{array}{l}0.5218 \\
(0.000)\end{array}$ \\
\hline \multirow{2}{*}{$\begin{array}{l}\text { Government } \\
\text { Training } \\
\text { Schemes }\end{array}$} & Compulsory & $\begin{array}{l}0.2477 \\
(0.135)\end{array}$ & $\begin{array}{l}\mathbf{0 . 3 7 9 6} \\
(0.022)\end{array}$ \\
\hline & $\begin{array}{c}\text { Voluntary } \\
\left(\varphi_{4}\right)\end{array}$ & & $\begin{array}{l}0.7893 \\
(0.000)\end{array}$ \\
\hline Gender & Male & $\begin{array}{l}\mathbf{0 . 8 4 3 7} \\
(0.000)\end{array}$ & $\begin{array}{l}\mathbf{0 . 8 3 2 9} \\
(0.000)\end{array}$ \\
\hline \multirow{3}{*}{ Human Capital } & Age & $\begin{array}{l}0.0545 \\
(0.172)\end{array}$ & $\begin{array}{l}0.0436 \\
(0.276)\end{array}$ \\
\hline & $\mathrm{Age}^{2}$ & $\begin{array}{l}-0.0990 \\
(0.105)\end{array}$ & $\begin{array}{c}-0.0870 \\
(0.156)\end{array}$ \\
\hline & University Graduate & $\begin{array}{l}0.2253 \\
(0.000)\end{array}$ & $\begin{array}{l}0.2342 \\
(0.000)\end{array}$ \\
\hline \multirow{5}{*}{$\begin{array}{l}\text { Workstatus } \\
\text { (base category } \\
\text { Full-Time } \\
\text { Employed) }\end{array}$} & Part Time Employed & $\begin{array}{l}\mathbf{0 . 3 5 1 6} \\
(0.000)\end{array}$ & $\begin{array}{l}\mathbf{0 . 3 5 4 7} \\
(0.000)\end{array}$ \\
\hline & Out of Work Force & $\begin{array}{l}0.3136 \\
(0.005)\end{array}$ & $\begin{array}{l}0.3244 \\
(0.004)\end{array}$ \\
\hline & Student & $\begin{array}{l}0.2113 \\
(0.175)\end{array}$ & $\begin{array}{l}0.2364 \\
(0.130)\end{array}$ \\
\hline & Unemployed & $\begin{array}{l}0.9091 \\
(0.000)\end{array}$ & $\begin{array}{l}0.9054 \\
(0.000)\end{array}$ \\
\hline & Economically Inactive & $\begin{array}{l}0.9728 \\
(0.000)\end{array}$ & $\begin{array}{l}0.9853 \\
(0.000)\end{array}$ \\
\hline
\end{tabular}

Notes: p-values in parenthesis; emboldened values are significant at the 5 percent level 
Table 4 - continued

\begin{tabular}{|c|c|c|c|}
\hline & & $\begin{array}{c}\text { Model } 1 \\
\text { No Control for } \\
\text { Voluntary Engagement } \\
\text { in Later Stage } \\
\text { Enterprise Education }\end{array}$ & $\begin{array}{c}\text { Model } 2 \\
\text { Controls for Voluntary } \\
\text { Engagement in Later } \\
\text { Stage Enterprise } \\
\text { Education }\end{array}$ \\
\hline \multirow{2}{*}{$\begin{array}{l}\text { Household } \\
\text { Income (base } \\
\text { category } \\
£ 17,500 \text { - } \\
£ 49,999)\end{array}$} & Under $£ 17,500$ & $\begin{array}{l}-0.0413 \\
(0.594)\end{array}$ & $\begin{array}{l}-0.0464 \\
(0.551)\end{array}$ \\
\hline & $£ 50,000$ or more & $\begin{array}{l}0.1228 \\
(0.091)\end{array}$ & $\begin{array}{l}0.1259 \\
(0.084)\end{array}$ \\
\hline \multirow{2}{*}{$\begin{array}{l}\text { Migration Status } \\
\text { (base category } \\
\text { Life-Long } \\
\text { Residents) }\end{array}$} & In-Migrants & $\begin{array}{l}0.2450 \\
(0.000)\end{array}$ & $\begin{array}{l}0.2538 \\
(0.000)\end{array}$ \\
\hline & Immigrants & $\begin{array}{l}0.8041 \\
(0.000)\end{array}$ & $\begin{array}{l}0.8037 \\
(0.000)\end{array}$ \\
\hline \multirow{2}{*}{$\begin{array}{l}\text { Environmental } \\
\text { Influences }\end{array}$} & LA Unemployment & $\begin{array}{r}-0.0148 \\
(0.696)\end{array}$ & $\begin{array}{l}-0.0203 \\
(0.595)\end{array}$ \\
\hline & Urban & $\begin{array}{r}-0.1163 \\
(0.097)\end{array}$ & $\begin{array}{l}-0.1153 \\
(0.102)\end{array}$ \\
\hline & Constant & $\begin{array}{l}-3.4586 \\
(0.000)\end{array}$ & $\begin{array}{l}-3.3092 \\
(0.000)\end{array}$ \\
\hline & $N$ & 16,343 & 16,343 \\
\hline & $R^{2}$ & 0.059 & 0.069 \\
\hline Perce & age Correct & 91.2 & 91.2 \\
\hline \multicolumn{2}{|c|}{ Hosmer-Lemeshow Test } & $\begin{array}{c}6.73 \\
(0.566)\end{array}$ & $\begin{array}{l}10.18 \\
(0.253)\end{array}$ \\
\hline \multicolumn{2}{|c|}{ LR test (null of constant probability) } & $\begin{array}{c}576.1 \\
{[28]} \\
(0.000)\end{array}$ & $\begin{array}{c}674.2 \\
{[29]} \\
(0.000)\end{array}$ \\
\hline \multicolumn{4}{|c|}{$\frac{\text { Mediation Tests }- \text { Compulsory School }}{\underline{\text { Based }}}$} \\
\hline \multicolumn{3}{|c|}{ Sobel (1982) Test of Product of Coefficients } & $\begin{array}{l}5.186 \\
(0.000)\end{array}$ \\
\hline \multicolumn{3}{|c|}{$\begin{array}{c}\text { MacKinnon et al. (1998) Test of Product of } \\
\text { Coefficients }\end{array}$} & $\begin{array}{l}5.186 \\
(0.000)\end{array}$ \\
\hline \multicolumn{3}{|c|}{$\begin{array}{l}\text { Freedman and Schatzkin (1992) Test of } \\
\text { Difference in Coefficients }\end{array}$} & $\begin{array}{l}19.681 \\
(0.000)\end{array}$ \\
\hline \multicolumn{4}{|c|}{ Mediation Tests - Voluntary School Based } \\
\hline \multicolumn{3}{|c|}{ Sobel (1982) Test of Product of Coefficients } & $\begin{array}{c}8.764 \\
(0.000)\end{array}$ \\
\hline \multicolumn{3}{|c|}{$\begin{array}{c}\text { MacKinnon et al. (1998) Test of Product of } \\
\text { Coefficients }\end{array}$} & $\begin{array}{l}8.764 \\
(0.000)\end{array}$ \\
\hline \multicolumn{3}{|c|}{$\begin{array}{l}\text { Freedman and Schatzkin (1992) Test of } \\
\text { Difference in Coefficients }\end{array}$} & $\begin{array}{l}12.718 \\
(0.000)\end{array}$ \\
\hline
\end{tabular}

Notes: $p$-values in parenthesis; emboldened values are significant at the 5 percent level 
Table 5 - Summary of key relationships between entrepreneurial intentions, compulsory school based enterprise education and voluntary later stage enterprise education and tests of mediation.

\begin{tabular}{|c|c|c|c|}
\hline \multirow[b]{2}{*}{$\begin{array}{l}\text { Panel A - v represents significant } \\
\text { result }\end{array}$} & \multicolumn{3}{|c|}{ Later Stage Enterprise Education } \\
\hline & University Based & $\begin{array}{l}\text { Formal Work } \\
\text { Placements }\end{array}$ & $\begin{array}{l}\text { Government } \\
\text { Training Schemes }\end{array}$ \\
\hline $\begin{array}{l}\text { Compulsory School Based } \rightarrow \\
\text { Voluntary Later Stage Enterprise } \\
\text { Education }\left(\varphi_{1}\right)\end{array}$ & $\vee$ & & $\vee$ \\
\hline $\begin{array}{l}\text { Compulsory School Based } \rightarrow \\
\text { Entrepreneurial Intentions (No } \\
\text { Controls for Voluntary Later Stage } \\
\text { Engagement) }\left(\varphi_{2}\right) \\
\text { Compulsory School Based } \rightarrow \\
\text { Entrepreneurial Intentions } \\
\text { (Controls for Voluntary Later } \\
\text { Stage Engagement) }\left(\varphi_{3}\right)\end{array}$ & & $\vee$ & $\checkmark$ \\
\hline $\begin{array}{l}\text { Voluntary Later Stage Enterprise } \\
\text { Education } \rightarrow \text { Entrepreneurial } \\
\text { Intentions }\left(\varphi_{4}\right)\end{array}$ & $\vee$ & $\vee$ & $\vee$ \\
\hline $\begin{array}{l}\text { Panel B - Tests of Mediation - } \\
\checkmark \text { represents significant result } \\
\text { indicating the presence of } \\
\text { mediation }\end{array}$ & University Based & $\begin{array}{l}\text { Formal Work } \\
\text { Placements }\end{array}$ & $\begin{array}{c}\text { Government } \\
\text { Training Schemes }\end{array}$ \\
\hline $\begin{array}{l}\text { Kenny et al. (1998) Significance } \\
\text { of } \varphi_{1} \text { and } \varphi_{4}\end{array}$ & $\checkmark$ & & $\checkmark$ \\
\hline $\begin{array}{l}\text { Sobel (1982) Test of Product of } \\
\text { Coefficients }\end{array}$ & 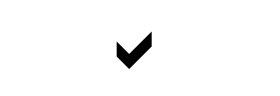 & & $V$ \\
\hline $\begin{array}{l}\text { MacKinnon et al. (1998) Test of } \\
\text { Product of Coefficients }\end{array}$ & $V$ & 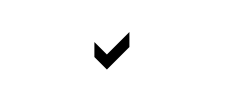 & $\checkmark$ \\
\hline $\begin{array}{l}\text { Freedman and Schatzkin (1992) } \\
\text { Test of Difference in Coefficients }\end{array}$ & $\checkmark$ & $\checkmark$ & $\checkmark$ \\
\hline
\end{tabular}


Table 6 - Binary logistic regressions of nascent entrepreneurship and the mediating influence of university based enterprise education (controlling for compulsory engagement)

\begin{tabular}{|c|c|c|c|}
\hline & & $\begin{array}{c}\text { Model } 1 \\
\text { No Control for } \\
\text { Voluntary Engagement } \\
\text { in Later Stage } \\
\text { Enterprise Education } \\
\end{array}$ & $\begin{array}{c}\text { Model } 2 \\
\text { Controls for Voluntary } \\
\text { Engagement in Later } \\
\text { Stage Enterprise } \\
\text { Education }\end{array}$ \\
\hline \multicolumn{4}{|l|}{$\begin{array}{l}\text { Participation in } \\
\text { Enterprise } \\
\text { Education (base } \\
\text { category no } \\
\text { participation) }\end{array}$} \\
\hline \multirow{2}{*}{ School Based } & $\begin{array}{l}\text { Compulsory } \\
\left(\varphi_{2} \text { and } \varphi_{3}\right)\end{array}$ & $\begin{array}{l}0.2160 \\
(0.274)\end{array}$ & $\begin{array}{l}0.1063 \\
(0.593)\end{array}$ \\
\hline & Voluntary & $\begin{array}{l}0.3288 \\
(0.014)\end{array}$ & $\begin{array}{l}0.1389 \\
(0.324)\end{array}$ \\
\hline \multirow{2}{*}{ University Based } & Compulsory & $\begin{array}{l}0.2810 \\
(0.117)\end{array}$ & $\begin{array}{l}\mathbf{0 . 4 3 3 1} \\
(0.017)\end{array}$ \\
\hline & $\begin{array}{c}\text { Voluntary } \\
\left(\varphi_{4}\right)\end{array}$ & & $\begin{array}{l}\mathbf{0 . 5 4 8 7} \\
(0.000)\end{array}$ \\
\hline Gender & Male & $\begin{array}{l}\mathbf{0 . 8 3 8 8} \\
(0.000)\end{array}$ & $\begin{array}{l}\mathbf{0 . 8 1 8 5} \\
(0.000)\end{array}$ \\
\hline \multirow{3}{*}{ Human Capital } & Age & $\begin{array}{l}\mathbf{0 . 1 4 4 2} \\
(0.030)\end{array}$ & $\begin{array}{l}\mathbf{0 . 1 4 2 9} \\
(0.032)\end{array}$ \\
\hline & $\mathrm{Age}^{2}$ & $\begin{array}{r}-0.2117 \\
(0.035)\end{array}$ & $\begin{array}{c}-0.2099 \\
(0.037)\end{array}$ \\
\hline & University Graduate & $\begin{array}{l}0.2740 \\
(0.006)\end{array}$ & $\begin{array}{l}0.2405 \\
(0.016)\end{array}$ \\
\hline \multirow{5}{*}{$\begin{array}{l}\text { Workstatus } \\
\text { (base category } \\
\text { Full-Time } \\
\text { Employed) }\end{array}$} & Part Time Employed & $\begin{array}{l}\mathbf{0 . 3 4 7 5} \\
(0.006)\end{array}$ & $\begin{array}{l}\mathbf{0 . 3 5 3 8} \\
(0.005)\end{array}$ \\
\hline & Out of Work Force & $\begin{array}{l}-0.1385 \\
(0.471)\end{array}$ & $\begin{array}{l}-0.1351 \\
(0.483)\end{array}$ \\
\hline & Student & $\begin{array}{r}-1.0402 \\
(0.014)\end{array}$ & $\begin{array}{r}-1.0566 \\
(0.013)\end{array}$ \\
\hline & Unemployed & $\begin{array}{l}0.2092 \\
(0.422)\end{array}$ & $\begin{array}{l}0.2104 \\
(0.419)\end{array}$ \\
\hline & Economically Inactive & $\begin{array}{l}0.7393 \\
(0.004)\end{array}$ & $\begin{array}{l}\mathbf{0 . 7 2 6 2} \\
(0.005)\end{array}$ \\
\hline
\end{tabular}

Notes: $p$-values in parenthesis; emboldened values are significant at the 5 percent level 
Table 6 - continued

\begin{tabular}{|c|c|c|c|}
\hline & & $\begin{array}{c}\text { Model } 1 \\
\text { No Control for } \\
\text { Voluntary Engagement } \\
\text { in Later Stage } \\
\text { Enterprise Education } \\
\end{array}$ & $\begin{array}{c}\text { Model } 2 \\
\text { Controls for Voluntary } \\
\text { Engagement in Later } \\
\text { Stage Enterprise } \\
\text { Education }\end{array}$ \\
\hline \multirow{2}{*}{$\begin{array}{c}\text { Household } \\
\text { Income (base } \\
\text { category } \\
£ 17,500 \text { - } \\
£ 49,999 \text { ) }\end{array}$} & Under $£ 17,500$ & $\begin{array}{l}0.2010 \\
(0.087)\end{array}$ & $\begin{array}{l}0.2037 \\
(0.083)\end{array}$ \\
\hline & $£ 50,000$ or more & $\begin{array}{r}-0.0258 \\
(0.823)\end{array}$ & $\begin{array}{r}-0.0415 \\
(0.719) \\
\end{array}$ \\
\hline \multirow{2}{*}{$\begin{array}{c}\text { Migration Status } \\
\text { (base category } \\
\text { Life-Long } \\
\text { Residents) }\end{array}$} & In-Migrants & $\begin{array}{l}0.1536 \\
(0.118)\end{array}$ & $\begin{array}{l}0.1613 \\
(0.101)\end{array}$ \\
\hline & Immigrants & $\begin{array}{l}0.1382 \\
(0.365)\end{array}$ & $\begin{array}{l}0.1001 \\
(0.515)\end{array}$ \\
\hline \multirow{2}{*}{$\begin{array}{l}\text { Environmental } \\
\text { Influences }\end{array}$} & LA Unemployment & $\begin{array}{r}-0.0485 \\
(0.418)\end{array}$ & $\begin{array}{r}-0.0501 \\
(0.404)\end{array}$ \\
\hline & Urban & $\begin{array}{r}-0.2025 \\
(0.051)\end{array}$ & $\begin{array}{r}-0.1886 \\
(0.069)\end{array}$ \\
\hline & Constant & $\begin{array}{l}-5.9894 \\
(0.000) \\
\end{array}$ & $\begin{array}{c}-6.0262 \\
(0.000)\end{array}$ \\
\hline & $N$ & 16,343 & 16,343 \\
\hline & $R^{2}$ & 0.032 & 0.037 \\
\hline Perce & age Correct & 96.7 & 96.7 \\
\hline \multicolumn{2}{|c|}{ Hosmer-Lemeshow Test } & $\begin{array}{c}6.29 \\
(0.615)\end{array}$ & $\begin{array}{c}9.81 \\
(0.278)\end{array}$ \\
\hline \multicolumn{2}{|c|}{ LR test (null of constant probability) } & $\begin{array}{c}154.4 \\
{[28]} \\
(0.000)\end{array}$ & $\begin{array}{c}175.8 \\
{[29]} \\
(0.000)\end{array}$ \\
\hline \multicolumn{4}{|c|}{$\frac{\text { Mediation Tests - Compulsory School }}{\underline{\text { Based }}}$} \\
\hline \multicolumn{2}{|c|}{ Sobel (1982) Test of Product of Coefficients } & & $\begin{array}{c}4.398 \\
(0.000)\end{array}$ \\
\hline \multicolumn{2}{|c|}{$\begin{array}{c}\text { Mackinnon et al. (1998) Test of Product of } \\
\text { Coefficients }\end{array}$} & & $\begin{array}{c}4.398 \\
(0.000)\end{array}$ \\
\hline \multicolumn{2}{|c|}{$\begin{array}{l}\text { Freedman and Schatzkin (1992) Test of } \\
\text { Difference in Coefficients }\end{array}$} & & $\begin{array}{c}8.239 \\
(0.000)\end{array}$ \\
\hline \multicolumn{4}{|c|}{ Mediation Tests - Voluntary School Based } \\
\hline \multicolumn{2}{|c|}{ Sobel (1982) Test of Product of Coefficients } & & $\begin{array}{c}4.744 \\
(0.000)\end{array}$ \\
\hline \multicolumn{2}{|c|}{$\begin{array}{c}\text { MacKinnon et al. (1998) Test of Product of } \\
\text { Coefficients }\end{array}$} & & $\begin{array}{c}4.744 \\
(0.000)\end{array}$ \\
\hline $\begin{array}{l}\text { Freedman and } \\
\text { Differen }\end{array}$ & $\begin{array}{l}\text { hatzkin (1992) Test of } \\
\text { in Coefficients }\end{array}$ & & $\begin{array}{c}5.084 \\
(0.000)\end{array}$ \\
\hline
\end{tabular}

Notes: p-values in parenthesis; emboldened values are significant at the 5 percent level 
Table 7 - Binary logistic regressions of nascent entrepreneurship and the mediating influence of formal work placements enterprise education (controlling for compulsory engagement)

\begin{tabular}{|c|c|c|c|}
\hline & & $\begin{array}{c}\text { Model } 1 \\
\text { No Control for } \\
\text { Voluntary Engagement } \\
\text { in Later Stage } \\
\text { Enterprise Education } \\
\end{array}$ & $\begin{array}{c}\text { Model } 2 \\
\text { Controls for Voluntary } \\
\text { Engagement in Later } \\
\text { Stage Enterprise } \\
\text { Education }\end{array}$ \\
\hline \multicolumn{4}{|l|}{$\begin{array}{l}\text { Participation in } \\
\text { Enterprise } \\
\text { Education (base } \\
\text { category no } \\
\text { participation) }\end{array}$} \\
\hline \multirow{2}{*}{ School Based } & $\begin{array}{l}\text { Compulsory } \\
\left(\varphi_{2} \text { and } \varphi_{3}\right)\end{array}$ & $\begin{array}{l}0.3126 \\
(0.109)\end{array}$ & $\begin{array}{l}0.3006 \\
(0.124)\end{array}$ \\
\hline & Voluntary & $\begin{array}{l}0.3464 \\
(0.010)\end{array}$ & $\begin{array}{l}\mathbf{0 . 3 2 4 7} \\
(0.017)\end{array}$ \\
\hline \multirow{2}{*}{$\begin{array}{l}\text { Formal Work } \\
\text { Placements }\end{array}$} & Compulsory & $\begin{array}{r}-0.2180 \\
(0.044)\end{array}$ & $\begin{array}{l}-0.1824 \\
(0.112)\end{array}$ \\
\hline & $\begin{array}{c}\text { Voluntary } \\
\left(\varphi_{4}\right)\end{array}$ & & $\begin{array}{l}0.1062 \\
(0.343)\end{array}$ \\
\hline Gender & Male & $\begin{array}{l}\mathbf{0 . 8 3 6 2} \\
(0.000)\end{array}$ & $\begin{array}{l}\mathbf{0 . 8 3 0 3} \\
(0.000)\end{array}$ \\
\hline \multirow{3}{*}{ Human Capital } & Age & $\begin{array}{l}\mathbf{0 . 1 4 5 3} \\
(0.029)\end{array}$ & $\begin{array}{l}\mathbf{0 . 1 4 3 9} \\
(0.030)\end{array}$ \\
\hline & $\mathrm{Age}^{2}$ & $\begin{array}{l}-0.2195 \\
(0.029)\end{array}$ & $\begin{array}{l}-0.2162 \\
(0.031)\end{array}$ \\
\hline & University Graduate & $\begin{array}{l}0.2910 \\
(0.003)\end{array}$ & $\begin{array}{l}0.2902 \\
(0.003)\end{array}$ \\
\hline \multirow{5}{*}{$\begin{array}{l}\text { Workstatus } \\
\text { (base category } \\
\text { Full-Time } \\
\text { Employed) }\end{array}$} & Part Time Employed & $\begin{array}{l}\mathbf{0 . 3 4 3 0} \\
(0.007)\end{array}$ & $\begin{array}{l}\mathbf{0 . 3 4 1 2} \\
(0.007)\end{array}$ \\
\hline & Out of Work Force & $\begin{array}{l}-0.1396 \\
(0.468)\end{array}$ & $\begin{array}{l}-0.1444 \\
(0.453)\end{array}$ \\
\hline & Student & $\begin{array}{r}-1.0450 \\
(0.014)\end{array}$ & $\begin{array}{r}-1.0460 \\
(0.014)\end{array}$ \\
\hline & Unemployed & $\begin{array}{l}0.2070 \\
(0.427)\end{array}$ & $\begin{array}{l}0.2089 \\
(0.422)\end{array}$ \\
\hline & Economically Inactive & $\begin{array}{l}\mathbf{0 . 7 3 4 1} \\
(0.004)\end{array}$ & $\begin{array}{l}\mathbf{0 . 7 3 4 1} \\
(0.004)\end{array}$ \\
\hline
\end{tabular}

Notes: $p$-values in parenthesis; emboldened values are significant at the 5 percent level 
Table 7 - continued

\begin{tabular}{|c|c|c|c|}
\hline & & $\begin{array}{c}\text { Model } 1 \\
\text { No Voluntary } \\
\text { Engagement in Later } \\
\text { Stage Enterprise } \\
\text { Education }\end{array}$ & $\begin{array}{c}\text { Model } 2 \\
\begin{array}{c}\text { Voluntary Engagement } \\
\text { in Later Stage } \\
\text { Enterprise Education }\end{array}\end{array}$ \\
\hline \multirow{2}{*}{$\begin{array}{l}\text { Household } \\
\text { Income (base } \\
\text { category } \\
£ 17,500- \\
£ 49,999 \text { ) }\end{array}$} & Under $£ 17,500$ & $\begin{array}{l}0.2001 \\
(0.089)\end{array}$ & $\begin{array}{l}0.1996 \\
(0.090)\end{array}$ \\
\hline & $£ 50,000$ or more & $\begin{array}{r}-0.0268 \\
(0.816)\end{array}$ & $\begin{array}{r}-0.0268 \\
(0.816)\end{array}$ \\
\hline \multirow{2}{*}{$\begin{array}{l}\text { Migration Status } \\
\text { (base category } \\
\text { Life-Long } \\
\text { Residents) }\end{array}$} & In-Migrants & $\begin{array}{l}0.1558 \\
(0.113)\end{array}$ & $\begin{array}{l}0.1563 \\
(0.112)\end{array}$ \\
\hline & Immigrants & $\begin{array}{l}0.1188 \\
(0.438)\end{array}$ & $\begin{array}{l}0.1161 \\
(0.448)\end{array}$ \\
\hline \multirow{2}{*}{$\begin{array}{l}\text { Environmental } \\
\text { Influences }\end{array}$} & LA Unemployment & $\begin{array}{l}-0.0497 \\
(0.407)\end{array}$ & $\begin{array}{l}-0.0491 \\
(0.413)\end{array}$ \\
\hline & Urban & $\begin{array}{l}-0.2073 \\
(0.045)\end{array}$ & $\begin{array}{l}-0.2059 \\
(0.047)\end{array}$ \\
\hline & Constant & $\begin{array}{r}-5.8709 \\
(0.000)\end{array}$ & $\begin{array}{l}-5.8913 \\
(0.000)\end{array}$ \\
\hline & $N$ & 16,343 & 16,343 \\
\hline & $R^{2}$ & 0.033 & 0.033 \\
\hline Perce & age Correct & 96.7 & 96.7 \\
\hline \multicolumn{2}{|c|}{ Hosmer-Lemeshow Test } & $\begin{array}{c}5.66 \\
(0.685)\end{array}$ & $\begin{array}{c}8.03 \\
(0.430)\end{array}$ \\
\hline \multicolumn{2}{|c|}{ LR test (null of constant probability) } & $\begin{array}{c}156.3 \\
{[28]} \\
(0.000)\end{array}$ & $\begin{array}{c}157.1 \\
{[29]} \\
(0.000)\end{array}$ \\
\hline \multicolumn{4}{|c|}{$\frac{\text { Mediation Tests - Compulsory School }}{\underline{\text { Based }}}$} \\
\hline \multicolumn{3}{|c|}{ Sobel (1982) Test of Product of Coefficients } & $\begin{array}{l}0.847 \\
(0.279)\end{array}$ \\
\hline \multicolumn{2}{|c|}{$\begin{array}{l}\text { MacKinnon et al. (1998) Test of Product of } \\
\text { Coefficients }\end{array}$} & & $\begin{array}{c}0.847 \\
(0.060)\end{array}$ \\
\hline \multicolumn{2}{|c|}{$\begin{array}{l}\text { Freedman and Schatzkin (1992) Test of } \\
\text { Difference in Coefficients }\end{array}$} & & $\begin{array}{c}8.528 \\
(0.000)\end{array}$ \\
\hline \multicolumn{4}{|c|}{ Mediation Tests - Voluntary School Based } \\
\hline \multicolumn{2}{|c|}{ Sobel (1982) Test of Product of Coefficients } & & $\begin{array}{c}0.947 \\
(0.255)\end{array}$ \\
\hline \multicolumn{2}{|c|}{$\begin{array}{c}\text { MacKinnon et al. (1998) Test of Product of } \\
\text { Coefficients }\end{array}$} & & $\begin{array}{c}0.947 \\
(0.040)\end{array}$ \\
\hline $\begin{array}{l}\text { Freedman and } \\
\text { Differen }\end{array}$ & $\begin{array}{l}\text { hatzkin (1992) Test of } \\
\text { in Coefficients }\end{array}$ & & $\begin{array}{c}1.144 \\
(0.253)\end{array}$ \\
\hline
\end{tabular}

Notes: p-values in parenthesis; emboldened values are significant at the 5 percent level 
Table 8 - Binary logistic regressions of nascent entrepreneurship and the mediating influence of government training schemes (controlling for compulsory engagement)

\begin{tabular}{|c|c|c|c|}
\hline & & $\begin{array}{c}\text { Model } 1 \\
\text { No Control for Voluntary } \\
\text { Engagement in Later } \\
\text { Stage Enterprise } \\
\text { Education }\end{array}$ & $\begin{array}{c}\text { Model } 2 \\
\text { Controls for Voluntary } \\
\text { Engagement in Later } \\
\text { Stage Enterprise } \\
\text { Education }\end{array}$ \\
\hline \multicolumn{4}{|l|}{$\begin{array}{l}\text { Participation in } \\
\text { Enterprise } \\
\text { Education (base } \\
\text { category no } \\
\text { participation) }\end{array}$} \\
\hline \multirow{2}{*}{ School Based } & $\begin{array}{l}\text { Compulsory } \\
\left(\varphi_{2} \text { and } \varphi_{3}\right)\end{array}$ & $\begin{array}{l}0.2724 \\
(0.161)\end{array}$ & $\begin{array}{l}0.1867 \\
(0.339)\end{array}$ \\
\hline & Voluntary & $\begin{array}{l}0.3379 \\
(0.012)\end{array}$ & $\begin{array}{l}0.1824 \\
(0.181)\end{array}$ \\
\hline \multirow{2}{*}{$\begin{array}{l}\text { Government } \\
\text { Training } \\
\text { Schemes }\end{array}$} & Compulsory & $\begin{array}{r}-0.0705 \\
(0.806)\end{array}$ & $\begin{array}{l}0.0940 \\
(0.744)\end{array}$ \\
\hline & $\begin{array}{c}\text { Voluntary } \\
\left(\varphi_{4}\right)\end{array}$ & & $\begin{array}{l}0.8989 \\
(0.000)\end{array}$ \\
\hline Gender & Male & $\begin{array}{l}\mathbf{0 . 8 4 3 8} \\
(0.000)\end{array}$ & $\begin{array}{l}\mathbf{0 . 8 2 3 4} \\
(0.000)\end{array}$ \\
\hline \multirow{3}{*}{ Human Capital } & Age & $\begin{array}{l}\mathbf{0 . 1 4 4 2} \\
(0.030)\end{array}$ & $\begin{array}{l}0.1291 \\
(0.052)\end{array}$ \\
\hline & $\mathrm{Age}^{2}$ & $\begin{array}{l}-0.2122 \\
(0.034)\end{array}$ & $\begin{array}{l}-0.1945 \\
(0.053)\end{array}$ \\
\hline & University Graduate & $\begin{array}{l}0.2870 \\
(0.004)\end{array}$ & $\begin{array}{l}0.2904 \\
(0.003)\end{array}$ \\
\hline \multirow{5}{*}{$\begin{array}{l}\text { Workstatus } \\
\text { (base category } \\
\text { Full-Time } \\
\text { Employed) }\end{array}$} & Part Time Employed & $\begin{array}{l}\mathbf{0 . 3 4 5 4} \\
(0.006)\end{array}$ & $\begin{array}{l}\mathbf{0 . 3 4 6 2} \\
(0.006)\end{array}$ \\
\hline & Out of Work Force & $\begin{array}{c}-0.1374 \\
(0.475)\end{array}$ & $\begin{array}{r}-0.1350 \\
(0.483)\end{array}$ \\
\hline & Student & $\begin{array}{c}-1.0448 \\
(0.014)\end{array}$ & $\begin{array}{c}-1.0072 \\
(0.018)\end{array}$ \\
\hline & Unemployed & $\begin{array}{l}0.2040 \\
(0.433)\end{array}$ & $\begin{array}{l}0.1901 \\
(0.467)\end{array}$ \\
\hline & Economically Inactive & $\begin{array}{l}\mathbf{0 . 7 3 2 7} \\
(0.004)\end{array}$ & $\begin{array}{l}\mathbf{0 . 7 5 3 1} \\
(0.003)\end{array}$ \\
\hline
\end{tabular}

Notes: p-values in parenthesis; emboldened values are significant at the 5 percent level 
Table 8 - continued

\begin{tabular}{|c|c|c|c|}
\hline & & $\begin{array}{c}\text { Model } 1 \\
\text { No Control for } \\
\text { Voluntary Engagement } \\
\text { in Later Stage } \\
\text { Enterprise Education } \\
\end{array}$ & $\begin{array}{c}\text { Model } 2 \\
\text { Controls for Voluntary } \\
\text { Engagement in Later } \\
\text { Stage Enterprise } \\
\text { Education }\end{array}$ \\
\hline \multirow{2}{*}{$\begin{array}{c}\text { Household } \\
\text { Income (base } \\
\text { category } \\
£ 17,500 \text { - } \\
£ 49,999)\end{array}$} & Under $£ 17,500$ & $\begin{array}{l}0.2017 \\
(0.086)\end{array}$ & $\begin{array}{l}0.1919 \\
(0.103)\end{array}$ \\
\hline & $£ 50,000$ or more & $\begin{array}{r}-0.0252 \\
(0.827)\end{array}$ & $\begin{array}{l}-0.0194 \\
(0.867)\end{array}$ \\
\hline \multirow{2}{*}{$\begin{array}{c}\text { Migration Status } \\
\text { (base category } \\
\text { Life-Long } \\
\text { Residents) }\end{array}$} & In-Migrants & $\begin{array}{l}0.1553 \\
(0.114)\end{array}$ & $\begin{array}{l}0.1616 \\
(0.101)\end{array}$ \\
\hline & Immigrants & $\begin{array}{l}0.1438 \\
(0.346)\end{array}$ & $\begin{array}{l}0.1309 \\
(0.393)\end{array}$ \\
\hline \multirow{2}{*}{$\begin{array}{l}\text { Environmental } \\
\text { Influences }\end{array}$} & LA Unemployment & $\begin{array}{r}-0.0498 \\
(0.406)\end{array}$ & $\begin{array}{r}-0.0552 \\
(0.358)\end{array}$ \\
\hline & Urban & $\begin{array}{l}-0.2045 \\
(0.048)\end{array}$ & $\begin{array}{l}-0.2011 \\
(0.053)\end{array}$ \\
\hline & Constant & $\begin{array}{l}-5.9722 \\
(0.000)\end{array}$ & $\begin{array}{l}-5.7632 \\
(0.000)\end{array}$ \\
\hline \multicolumn{2}{|r|}{$N$} & 16,343 & 16,343 \\
\hline \multicolumn{2}{|r|}{$R^{2}$} & 0.032 & 0.044 \\
\hline \multicolumn{2}{|c|}{ Percentage Correct } & 96.7 & 96.7 \\
\hline \multicolumn{2}{|c|}{ Hosmer-Lemeshow Test } & $\begin{array}{c}8.92 \\
(0.349)\end{array}$ & $\begin{array}{c}9.78 \\
(0.281)\end{array}$ \\
\hline \multicolumn{2}{|c|}{ LR test (null of constant probability) } & $\begin{array}{c}152.1 \\
{[28]} \\
(0.000)\end{array}$ & $\begin{array}{c}211.4 \\
{[29]} \\
(0.000)\end{array}$ \\
\hline \multicolumn{4}{|c|}{$\frac{\text { Mediation Tests }- \text { Compulsory School }}{\text { Based }}$} \\
\hline \multicolumn{3}{|c|}{ Sobel (1982) Test of Product of Coefficients } & $\begin{array}{c}4.843 \\
(0.000)\end{array}$ \\
\hline \multicolumn{2}{|c|}{$\begin{array}{c}\text { Mackinnon et al. (1998) Test of Product of } \\
\text { Coefficients }\end{array}$} & & $\begin{array}{c}4.843 \\
(0.000)\end{array}$ \\
\hline \multicolumn{2}{|c|}{$\begin{array}{l}\text { Freedman and Schatzkin (1992) Test of } \\
\text { Difference in Coefficients }\end{array}$} & & $\begin{array}{l}17.002 \\
(0.000)\end{array}$ \\
\hline \multicolumn{4}{|c|}{ Mediation Tests - Voluntary School Based } \\
\hline \multicolumn{2}{|c|}{ Sobel (1982) Test of Product of Coefficients } & & $\begin{array}{l}7.357 \\
(0.000)\end{array}$ \\
\hline \multicolumn{2}{|c|}{$\begin{array}{l}\text { MacKinnon et al. (1998) Test of Product of } \\
\text { Coefficients }\end{array}$} & & $\begin{array}{l}7.357 \\
(0.000)\end{array}$ \\
\hline $\begin{array}{l}\text { Freedman and } \\
\text { Differen }\end{array}$ & $\begin{array}{l}\text { hatzkin (1992) Test of } \\
\text { in Coefficients }\end{array}$ & & $\begin{array}{c}9.586 \\
(0.000)\end{array}$ \\
\hline
\end{tabular}

Notes: $p$-values in parenthesis; emboldened values are significant at the 5 percent level 
Table 9 - Summary of key relationships between nascent entrepreneurship, compulsory school based enterprise education and voluntary later stage enterprise education and tests of mediation.

\begin{tabular}{|c|c|c|c|}
\hline \multirow[b]{2}{*}{$\begin{array}{l}\text { Panel A - } \checkmark \text { represents significant } \\
\text { result }\end{array}$} & \multicolumn{3}{|c|}{ Later Stage Enterprise Education } \\
\hline & University Based & $\begin{array}{l}\text { Formal Work } \\
\text { Placements }\end{array}$ & $\begin{array}{l}\text { Government } \\
\text { Training Schemes }\end{array}$ \\
\hline $\begin{array}{l}\text { Compulsory School Based } \rightarrow \\
\text { Voluntary Later Stage Enterprise } \\
\text { Education }\left(\varphi_{1}\right)\end{array}$ & $\vee$ & & $\vee$ \\
\hline $\begin{array}{l}\text { Compulsory School Based } \rightarrow \\
\text { Nascent Entrepreneurship (No } \\
\text { Controls for Voluntary Later Stage } \\
\text { Engagement) }\left(\varphi_{2}\right) \\
\text { Compulsory School Based } \rightarrow \\
\text { Nascent Entrepreneurship } \\
\text { (Controls for Voluntary Later } \\
\text { Stage Engagement) }\left(\varphi_{3}\right)\end{array}$ & & & \\
\hline $\begin{array}{l}\text { Voluntary Later Stage Enterprise } \\
\text { Education } \rightarrow \text { Nascent } \\
\text { Entrepreneurship }\left(\varphi_{4}\right)\end{array}$ & $\vee$ & & $\vee$ \\
\hline $\begin{array}{l}\text { Panel B - Tests of Mediation - } \\
\checkmark \text { represents significant result } \\
\text { indicating the presence of } \\
\text { mediation }\end{array}$ & University Based & $\begin{array}{l}\text { Formal Work } \\
\text { Placements }\end{array}$ & $\begin{array}{c}\text { Government } \\
\text { Training Schemes }\end{array}$ \\
\hline $\begin{array}{l}\text { Kenny et al. (1998) Significance } \\
\text { of } \varphi_{1} \text { and } \varphi_{4}\end{array}$ & $\vee$ & & $\checkmark$ \\
\hline $\begin{array}{l}\text { Sobel (1982) Test of Product of } \\
\text { Coefficients }\end{array}$ & $\checkmark$ & & $\checkmark$ \\
\hline $\begin{array}{l}\text { MacKinnon et al. (1998) Test of } \\
\text { Product of Coefficients }\end{array}$ & $\checkmark$ & & $\checkmark$ \\
\hline $\begin{array}{l}\text { Freedman and Schatzkin (1992) } \\
\text { Test of Difference in Coefficients }\end{array}$ & $\checkmark$ & $\checkmark$ & $\checkmark$ \\
\hline
\end{tabular}


Figure 1 - Mediating effect of voluntary later stage enterprise education on the relationship between compulsory school based enterprise education and entrepreneurial activity

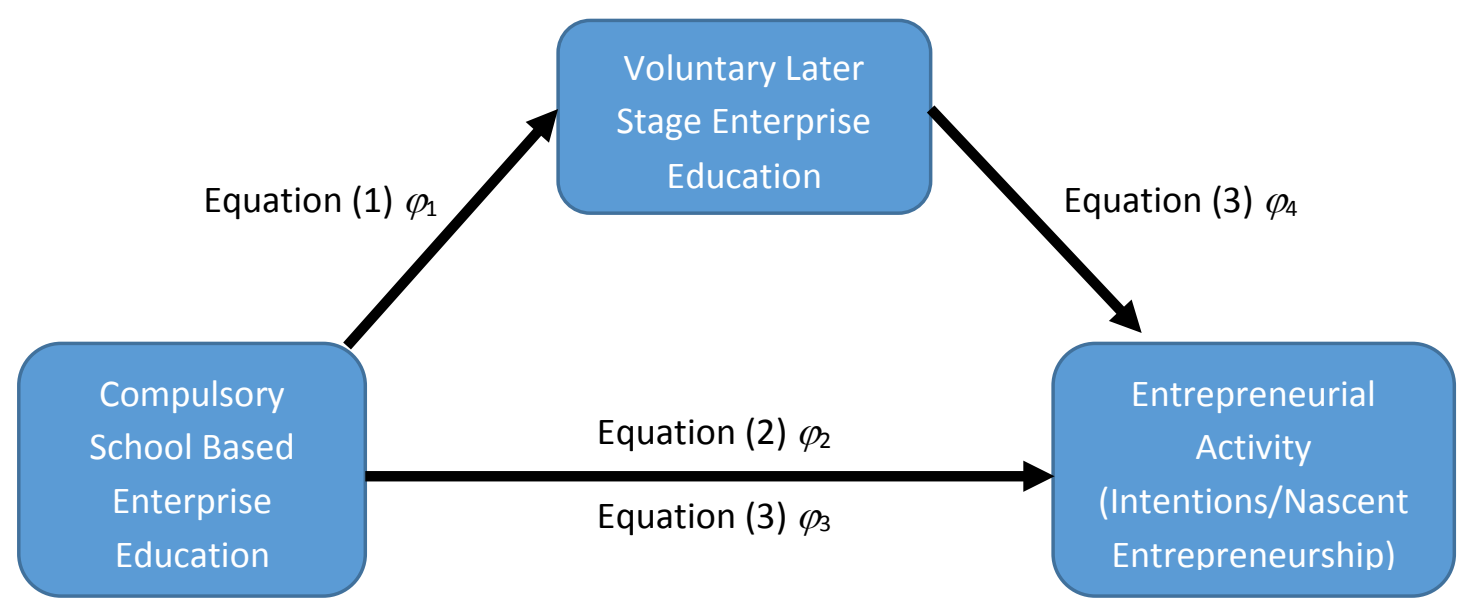

